\title{
AZ INFORMATIKA HELYZETE ÉS LEHETŐSÉGEI A MAGYAR NAGYVÁLLALATOK MARKETING- ÉS ÉRTÉKESÍTÉSI TEVÉKENYSÉGÉNEK TÁMOGATÁSÁBAN
}

A marketingtevékenység informatikai támogatottsága - Magyarországon és külföldön egyaránt - elmarad a többi vállalati szakterület átlagától. Az elmúlt években azonban megváltozni látszik ez a helyzet: a CRMalkalmazások (Customer Relationship Management - ügyfélkapcsolat-kezelés), amelyek leginkább a marketingfunkcióhoz köthetốk, ugyanis a vállalatirányítási szoftverek legdinamikusabban fejlôdố részpiacává váltak. A szerzố kutatásában áttekinti, hogy az informatika milyen szerepet kap, és milyen lehetôségeket rejt a legnagyobb árbevétellel rendelkezó magyar vállalatok marketingmenedzsment munkájában. Eredményei szerint a magyar nagyvállalatok 13 százaléka használ csupán korszerú CRM-alkalmazásokat, és a menedzserek 13 százaléka véli csak úgy, hogy a piaci tájékozódásban az informatikai alkalmazásoknak kiemelt szerepük van. Ennek az is az oka lehet, hogy a megvizsgált vállalatok rendszerei nem tartalmazzák teljes körúen a klasszikus marketingmunkához szükséges információkat. Érdekes eredmény, hogy a marketingmenedzserek mégsem az IT-rendszerek adattartalma alapján alkotnak véleményt az alkalmazások hasznosságáról: akkor támaszkodnak munkájuk során a számítógépekre, ha megfelelő felhasználói képzésben részesültek és ,felhasználóbarátnak” ítélik az informatikai rendszert.

\section{Kulcsszavak: marketing, informatika, CRM, Magyarország}

A marketinginformatika legtöbb külföldi és magyar kutatója egyetért abban, hogy ez a terület sokáig meglehetôsen ,elhanyagolt” volt szoftveres támogatás szempontjából. Ezt látszik igazolni egy tanszéki kutatásunk is, amelyben valamennyi magyar piacon kapható vállalatirányítási szoftvert megvizsgáltuk. Amíg a legtöbb vállalati szakterület munkájának támogatására kész csomagot kínálnak az IT-alkalmazások, addig a marketingmodul hiányzik palettájukról (Keszey, 2003).

Úgy túnik azonban, hogy az Economist 2001-es prognózisa helyes volt, hiszen valóban a marketinghez kapcsolódó alkalmazások területén volt a legjelentôsebb az informatikai piac bóvülése az elmúlt néhány évben (Economist, 2001). A Figyelố szerint a CRM (Customer Relationship Management - ügyfélkapcsolat-kezelés) - amely leginkább a marketingfunkcióhoz köthető - a vállalatirányítási szoftverek egyik legnagyobb és leggyorsabban fejlődő szegmense (Figyelő, 2005. szeptember 12.). A CRM mint marketingkoncepció nem új. Az ügyfélkapcsolat-menedzsment célja az értékes fogyasztók megszerzése és megtartása, lojalitásuk növelése olyan marketingprogramok segítségével, amelyek valós igényeik megismerésén alapulnak (Swift, 2001). Az informatikai alkalmazások ezt a tevékenységet a marketingprogramok személyre szabásával; a „one-to-one” marketing lehetőségének megteremtésével képesek hathatósan támogatni. Az IT-alkalmazások ugyanis módot adnak minden egyes vevớrôl nagy mennyiségú és sokrétú adat ${ }^{2}$ rögzítésére és elemzésére (pl. minden egyes ügyfél értékének meghatározása; a várható lemorzsolódás elốrejelzése stb.), a vevơi kapcsolattartás gördülékenyebbé tételére 
(pl. a vállalattal történô interakciók - telefonhívások, weboldal számítógépes támogatása) és hatékonyabb, célzottabb, az egyedi igényekre reflektáló marketingprogramok kidolgozására.

$\mathrm{Az}$ informatika marketingmenedzsment munkában betöltött szerepének felértékelődése mögött az a megállíthatatlan tendencia húzódik, hogy a vevôi elégedettség átlagos mértéke az elmúlt évtizedben valamennyi szektorban csökkent. A University of Michigan 1994 óta méri rendszeresen különböző iparágakban az amerikai fogyasztók elégedettségi indexét (American Customer Satisfaction Index; http://theacsi.org). Méréseik szerint például a lap- és könyvkiadásban átlagosan 12,5 százalékkal. a repülővel történő személyszállításban 8,4 százalékkal, míg a személyi számítógépek piacán 9 százalékkal csökkent a vevôi elégedettség indexe 1994 és 2004 között. Jóllehet a korábbi empirikus kutatások csak részben tudták igazolni, mégis úgy tưnik, hogy a vevői elégedettség fontos szerepet játszik a vevooi lojalitás kialakításában (Anderson - Mittal, 2000) és végsô soron a versenyképesség és a sikeres gazdasági teljesítmény megteremtésében (Hart, 2007). A marketingheurisztikák szerint ötször annyiba kerül egy új ügyfelet megszerezni, mint egy régi vevőt megtartani. A vevőmegtartás szerepe tehát fontosabb, mint valaha; és a CRM-rendszerek pedig épp ezen a ponton tudják hatékonyabbá tenni a marketingmunkát.

A marketinginformatika és a CRM témaköre iránti vállalati gyakorlat oldaláról érkezó érdeklődés mellett szükség van a témakör akadémiai igényư feltárására is. Ennek jegyében a rangos Journal of Marketing folyóirat 2005 októberében az egész számot ennek a témának szentelte. A magyar menedzsment-szakirodalomban is számos hiánypótló publikáció jelent meg az utóbbi években (Szabó - Hámori, 2006; Mester, 2006; Bokker, 2002; Büdy, 2001). Mégis, keveset tudunk arról, hogyan vélekednek a magyar nagyvállalatok marketingmenedzserei az informatika menedzsmentmunkában betöltött szerepéról, és mennyire tartják a számítástechnikai eszközöket fontosnak a piaci tájékozódásban.

Kutatásunk az első olyan munka, amelyben megvizsgáljuk, hogy az informatika milyen szerepet kap a marketing-információrendszeren (MIR) belül, mennyire tartják fontos eszköznek a piaci tájékozódás során a vezetók. A korábbi tanulmányok önmagukban vizsgálták az informatikai alkalmazásokat, így nem adtak választ arra a nagyon fontos kérdésre, hogy az IT milyen hatással van a marketingmunkára. Eredményeink szerint az informatika egyelöre nem játszik fontos szerepet a magyar nagyvállalatok marketingmenedzsment munkájában; a vezetôk legszívesebben piaci pletykák, szórvány információk, esetleg piackutatások segítségével tájékozódnak a versenytársakról és a vevoók igényeiról. A magyar menedzserek 13 százaléka tartja csupán a számítógépeket az informálódás legfontosabb eszközének. A magyar nagyvállalati vezetôk 58 százaléka véli úgy, hogy az informatika nagy hatással van a marketingmunkára - ugyanez az érték 85 százalék volt az angol menedzserek körében egy évtizeddel a mi felmérésünk előtt.

A kutatásban megvizsgáljuk nagyvállalataink marketinginformatikai alkalmazásainak sajátosságait, áttekintjük, milyen adatokat, információkat tárolnak a rendszerekben, és megvizsgáljuk, hogy a számítástechnikai alkalmazások képesek-e teljes spektrumában lefedni a marketingmenedzserek információigényeit. A legtöbb nagyvállalat kereskedelmi jellegú adatokat tárol, a klasszikus marketingmenedzsmenthez szükséges információkat a megvizsgált vállalatok elenyészô hányada képes csupán elóhívni informatikai alkalmazásaiból. Korszerú CRM-rendszereket a vizsgált nagyvállalatok 13 százaléka alkalmaz, tehát a tények nem tükrözik azt a „csodavárást”, ami körüllengi a témát. A Népszabadság szerint például a magyar vezetók a CRM-et tartják annak a legfontosabb eszköznek, amellyel jelentősen javítható a vállalat eredményessége (Népszabadság, 2006. október 19.), Winer (2001) pedig - kissé cinikusan - a marketing új ,,mantrájának” nevezi a CRM-et.

Kutatásunkban fontosnak tartottuk azt is megismerni, hogy melyek azok a tényezók, amelyek leginkább hozzájárulnak ahhoz, hogy egy nagyvállalati marketingvezető mindennapi munkája szempontjából hasznosnak tartsa az általa használt informatikai rendszereket. Az eredmény tanulságos: a számítástechnikai alkalmazások minôségének megítélésében a legfontosabb tényezô az, hogy a marketingmenedzser képes-e használni a rendszert. Hiába fordít egy vállalat jelentős összegeket korszerú IT-rendszerek kiépítésére, az csak akkor jelent a munkához hozzáadott értéket, ha a vezető megfelelő számítógép-felhasználói ismeretekkel rendelkezik; kiterjedt végfelhasználói képzésben részesült, és az IT-alkalmazás „felhasználóbarát”.

\section{Az informatika marketing- munkára gyakorolt hatása és szerepe a marketing-információrendszerben}

Vizsgálatainkat a legnagyobb (négymilliárd forintot meghaladó) éves árbevétellel rendelkező vállalataink teljes körú megkérdezésén alapuló mintán végeztuik. A kérdőíves megkérdezés során 254 vállalattól kaptunk választ, ez 26 százalékos válaszadási aránynak felel 
meg. Az elemzésünkbe bevont vállalatok 10 százaléka állami, 37 százaléka magyar magán-, 53 százaléka külföldi tulajdonban van. A minta több mint 50 százalékát 300 fốnél többet foglalkoztató vállalatok alkotják. A válaszadó marketingmenedzserek átlagosan 8 éve dolgoznak jelenlegi munkakörükben, jellemzően középvezető beosztásban. A minta profilját részletesen értékeljük a tanulmány módszertani fejezetében.

\section{Hogyan vélekednek az informatikáról a magyar nagyvállalatok marketingvezetôi?}

Kutatásunkban elôször arra voltunk kíváncsiak, hogy nagyvállalataink marketingvezetói hogyan vélekednek az informatika marketingre gyakorolt hatásáról. A jelenség két metszetét, a felhasználó és az informatika viszonyát, valamint az IT szervezetre gyakorolt hatását vizsgáltuk. ni szint), illetve mitól függ az informatika vállalati teljesítményre gyakorolt hatása (szervezeti szint).

A magyar menedzserek informatikával szembeni attitúdje jóllehet összességében pozitívnak mondható, az eredményeket némileg árnyalja Leverick, Litter et al. (1997) felmérése. Az Egyesült Királyság területén végzett, 111 vállalatot érintő felmérésük szerint ugyanis az 1990-es évek közepén a válaszadók 85 százaléka érezte úgy, hogy az informatika jelentôs hatással van a marketingtevékenységre (Leverick - Litter et al., 1997) szemben a magyar nagyvállalatok vezetôinek 58 százalékos pozitív válaszával - egy évtizeddel késốbb.

\section{Az informatika marketing-információ- rendszerben (MIR) betöltött szerepe}

A marketing-információrendszer a különböző külső és belsố információk koordinált és folyamatos gyuuj-

Véleménye szerint milyen szerepet játszik a marketingmenedzsmentben az információtechnológia?

\begin{tabular}{|c|c|c|c|c|c|c|c|c|c|c|}
\hline & Átlag & Szórás & 1 & 2 & 3 & 4 & 5 & $\begin{array}{l}\text { NT/ } \\
\text { NV }\end{array}$ & $\begin{array}{c}\text { Össze- } \\
\text { sen }\end{array}$ & $\begin{array}{c}\text { Hi- } \\
\text { ányzó }\end{array}$ \\
\hline $\begin{array}{l}\text { Az informatikai rendszereket hasznosnak } \\
\text { tartom munkám szempontjából }\end{array}$ & 3,89 & 1,07 & $2,8(7)$ & $3,7(9)$ & $\begin{array}{l}14,2 \\
(35)\end{array}$ & $\begin{array}{l}49,6 \\
(122)\end{array}$ & $\begin{array}{l}27,6 \\
(68)\end{array}$ & $2,0(5)$ & $\begin{array}{c}100 \\
(246)\end{array}$ & 16 \\
\hline $\begin{array}{l}\text { Vállalatunknál az informatika } \\
\text { alkalmazása jelentős hatással van a } \\
\text { marketingmunkára }\end{array}$ & 3,50 & 1,09 & $3,9(9)$ & $\begin{array}{l}14,2 \\
(35)\end{array}$ & $\begin{array}{l}23,9 \\
(59)\end{array}$ & $\begin{array}{c}40,9 \\
(101)\end{array}$ & $\begin{array}{l}16,6 \\
(41)\end{array}$ &, $8(2)$ & $\begin{array}{c}100 \\
(247)\end{array}$ & 13 \\
\hline
\end{tabular}

Megj.: 1 - egyáltalán nem ért egyet; 5 - teljes mértékben egyetért

Az 1. táblázatban található eredmények alapján azt mondhatjuk, hogy az informatika a legtöbb marketingmenedzser munkájára hatással van. A válaszadók 77 százaléka hasznosnak tartja az IT-rendszereket - míg csupán 6,5 százalékuk vélekedik úgy, hogy a számítógépek nem támogatják érdemben a munkájukat. Az informatika szervezeti hatását kevesebb menedzser - a válaszadók 58 százaléka - érzi jelentősnek. Elgondolkodtató, hogy majdnem minden ötödik nagyvállalati vezető véli úgy, hogy az informatika nincs, vagy egyáltalán nincs jelentős hatással a cég marketingmunkájára.

A menedzserek szerint tehát az informatika eltéró módon hatja át saját mindennapi munkájukat, és a vállalat marketingtevékenységének egészét - az elóbbire nagyobb hatást gyakorolva. Van Bruggen és Wierenga (2005) szerint a kutatások többsége nem tesz különbséget az IT felhasználói és szervezeti hatásai között, pedig ez fontos lenne, mivel eltéró lehet a számítástechnika jelentősége az egyén és a vállalat szintjén. Van Bruggen és Wierenga (2005) szerint eltérő tényezók befolyásolják, hogy hasznosnak tartja-e a marketingvezető az informatikát döntései meghozatala során (egyé- tését, feldolgozását, szelektálását, tárolását, áramoltatását, és azok megjelenítését megvalósító rendszer (Bauer - Berács, 2006). Kutatásunkban a marketinginformációrendszer (MIR) három fontos komponensének: a piackutatásnak, a piaci értesüléseknek (market intelligence) $^{3}$ és az informatikai rendszereknek a piaci tájékozódásban betöltött szerepét is vizsgáltuk.

A marketingkutatók egyetértenek abban, hogy ezek lényeges eszközök a marketingkörnyezet feltérképezésében, a versenytársakról, a fogyasztókról való tájékozódásban, mégis kevesebbet tudunk arról, hogy egy probléma megoldása vagy egy döntés meghozatala során hogyan tájékozódnak legszívesebben a magyar marketingszakemberek. A kutatásunkban górcsố alá vett három komponens MIR-ben betöltött relatív súlyának akadémiai igényú feltárásával annak ellenére adós a marketingtudomány, hogy több olyan tanulmány is készült, amely különállóan vizsgálta az említett információforrások marketingmenedzsmentben betöltött szerepét.

Kérdőívünkben arra kértük a marketingvezetôket, hogy észlelt fontosság szerint rangsorolják a marketing-információrendszer vizsgálatba bevont három öszszetevôjét (1. ábra). 
1. ábra

Munkájához kötődően

az alábbi információforrások közül melyiket tartja a legfontosabbnak?

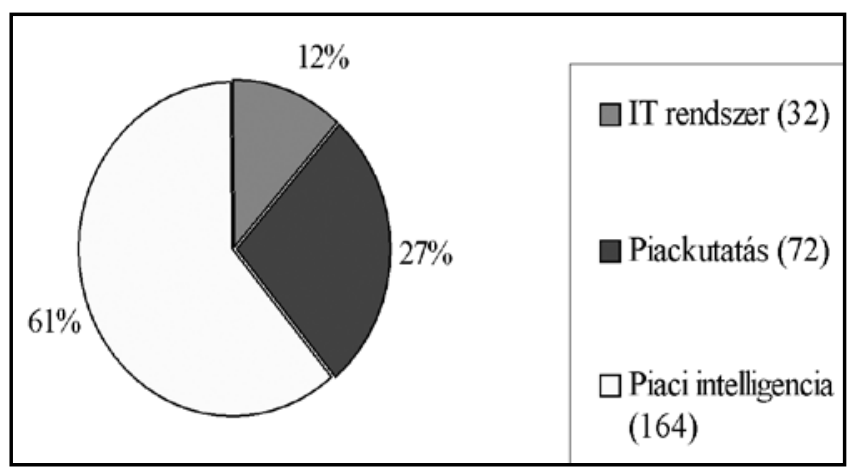

Megj.: a kérdőívben válaszadóinkat arra kértük, hogy rangsorolják, munkájukhoz kötődően mennyire tartják fontosnak a piackutatásokat; az információtechnológiai alkalmazásokat és a piaci megfigyeléseket, értesüléseket.

A marketingvezetók közel kétharmada a legfontosabbnak a piaci intelligenciát, a piaci megfigyeléseket tartja a piaci információk megszerzésében. A magyar nagyvállalatok egynegyedénél a piackutatásokat; míg információtechnológiai alkalmazásokat megközelítóleg egytizedénél gondolják a legfontosabbnak a menedzserek.

Az eredményeket részletesebb vizsgálatából (2. táblázat) látható, hogy a legtöbb válaszadó a piaci értesüléseket tartja a legfontosabbnak, a piackutatást közepesen fontosnak és az informatikát pedig a legkevésbé fontosnak a tájékozódásban.

2. táblázat

Munkájához kötődően az alábbi információforrásokat mennyire tartja fontosnak?

\begin{tabular}{|l|c|c|c|}
\hline & $\begin{array}{c}\text { Piaci } \\
\text { értesülések }\end{array}$ & Piackutatás & $\begin{array}{c}\text { Informatikai } \\
\text { alkalmazások }\end{array}$ \\
\hline Legfontosabb & $65,9(164)$ & $29,6(72)$ & $13,2(32)$ \\
\hline Közepesen fontos & $22,1(55)$ & $43,6(106)$ & $33,3(81)$ \\
\hline $\begin{array}{l}\text { Legkevésbé } \\
\text { fontos }\end{array}$ & $12,0(30)$ & $26,7(65)$ & $53,5(130)$ \\
\hline Hiányzó & $-(11)$ & $-(17)$ & $-(17)$ \\
\hline Összesen & $\mathbf{1 0 0}(\mathbf{2 6 0})$ & $\mathbf{1 0 0}(\mathbf{2 6 0})$ & $\mathbf{1 0 0}(\mathbf{2 6 0})$ \\
\hline
\end{tabular}

A 2. táblázatból az is kitúnik, hogy a piackutatás szerepének megítélése a legkiegyenlítettebb; közel ugyanannyian tartják a legfontosabb, mint a legkevésbé fontos eszköznek. A piaci szórványinformációk értelmezése egyértelmúen a domináns és a legfontosabbnak tartott tájékozódási mód (a válaszadók 88 százaléka szerint a két legfontosabb vizsgált eszköz között van). Az IT szerepének megítélése ezzel épp ellentétes, hiszen a válaszadók 87 százaléka szerint kevéssé vagy közepesen fontosak a számítógépek.

\section{Az informatika-intenzív nagyvállalati kör sajátosságai}

Vizsgáltuk $^{4}$, hogy miben különböznek társaiktól azok a vállalatok és menedzserek, akik az informatikai rendszereket a legfontosabb piaci hírforrásnak tartó 13 százalékba tartoznak. A vizsgálat során a múködési piac, a szervezet sajátosságai, a vezetô döntéshozatali stílusa és munkaköri tapasztalata szerinti eltéréseket vizsgáltuk.

Nem találtunk a múködési környezet sajátosságai és az informatika piaci tájékozódásban betöltött szerepe között szignifikáns kapcsolatot. Vizsgáltuk, hogy az informatikát a legfontosabb hírforrásnak tekintố vállalatok másképp gondolkodnak-e a vevók igényeiról, vagy a technológia iparági jelentőségéról; azonban nem találtunk szignifikáns eltéréseket. Hasonlóan az iparági besorolás, az előállított termék típusa, vagy a B2B (ipari), illetve $\mathrm{B} 2 \mathrm{C}$ (fogyasztói) piaci jelenlét dominanciája alapján sem körvonalazható a magyar nagyvállalatok tizenhárom százalékát magában foglaló informatika-intenzív csoport. Megvizsgáltuk a múködési piac életgörbéje, a vállalat piaci pozíciója és stratégiai prioritásai szerinti eltéréseket; azonban szignifikáns különbségeket itt sem találtunk a piackutatásokat, IT-rendszereket és a piaci intelligenciát a legfontosabbnak tartó vállalatok között.

A szervezet sajátosságai közül vizsgáltuk, hogy körülírható-e az informatika-intenzív nagyvállalati csoport aszerint, hogy milyen mértékben múlik a vezetô javadalmazása a piaci teljesítményen, vagy hány fốt alkalmaz a vállalat, milyen a tulajdonosi struktúrája és mennyire szoros az anyavállalathoz fúző́dő viszonya. Áttekintettük a különbségeket a vállalat által alkalmazott informatikai rendszer fejlettsége, a vállalaton belüli változások üteme és a marketingfunkciónak a szervezeti felépítésben elfoglalt helye szerint, azonban szignifikáns eltéréseket itt sem tapasztaltunk.

A marketing-döntéshozót leíró változók között kérdéseket tettünk fel arra vonatkozóan, hogy mennyire kötődik érzelmileg munkahelyéhez, valamint döntéshozatali stílusával kapcsolatosan is fogalmaztunk meg állításokat; de ezek alapján sem találtunk eltéréseket, mint ahogyan a beosztás, illetve a vállalati hierarchiában elfoglalt pozíció sem volt informatív. Az egyetlen vizsgált tényezó, amely szignifikánsan eltér az informatikát kiemelten fontosnak tartó vezetốk és társaik között az években kifejezett munkaköri tapasztalat (3. táblázat). 


\section{A munkaköri tapasztalat és a vezetôi tájékozódás módjainak összefüggései}

\begin{tabular}{|c|c|}
\hline $\begin{array}{c}\text { Melyik információforrást tartja a piaci } \\
\text { tájékozódás legfontosabb eszközének? }\end{array}$ & $\begin{array}{c}\text { Hány éve dolgozik } \\
\text { az üzletágnál? }\end{array}$ \\
\hline Piaci intelligencia & 8,5 \\
\hline Piackutatás & 9,1 \\
\hline Információtechnológiai alkalmazások & 13,2 \\
\hline Átlag & 9,5 \\
\hline
\end{tabular}

Meg.: $\mathrm{F}=3,68$, sig. $=, 027 * *$

Eredményeink szerint azok a marketing-döntéshozók, akik az információtechnológiai alkalmazásokat tartották a piaci tájékozódás legfontosabb eszközének átlagosan kicsivel több mint 13 éve dolgoznak jelenlegi üzletáguknál; 4 évvel hosszabb ideje, mint a piackutatást, és 4,5 évvel hosszabb ideje, mint a piaci intelligenciát a legfontosabbnak tartó menedzser társaik.

Megvizsgáltuk, hogy a témakör nemzetközi szakirodalmában a korábbi kutatások vizsgálták-e ezt az - elsố megközelítésben meglepő - összefüggést. Kiderült, hogy több korábbi tanulmány (Taylor, 1975; Wierenga - Ophuis, 1997; Zinkhan - Joachimsthaler et al., 1987) is kimutatott összefüggést a menedzser életkora és az információkeresési minták között. A kutatók arra jutottak, hogy az idôsebb vállalatvezetốk döntéseiknél több információt mérlegelnek, az informatikai rendszerek pedig épp ezt segítik, hiszen nagy mennyiségú piaci adat tárolására és elóhívására biztosítanak lehetôséget. Van Bruggen és Wierenga (2005) a CRM-rendszerek kedvezô megítélése és a marketingmenedzserek életkora között mutatott ki pozitív kapcsolatot. Eredményeink párhuzamba állíthatók ezekkel a kutatásokkal, azonban a vezetók tapasztalata és az informatikai rendszerek hasznosságának megítélése további vizsgálatokat igényel.

\section{Nagyvállalataink marketinginformatikai rend- szereinek sajátosságai}

\section{Milyen marketingadatokat tárolnak nagyvállala-} taink informatikai rendszereikben?

Kutatásunkban feltártuk, hogy nagyvállalataink informatikai rendszerei milyen típusú marketingadatokat milyen részletesen tárolnak. A marketingadatok vizs-

\section{Milyen részletességgel tárolják az alábbi marketingadatokat vállalatuk informatikai rendszerei?}

\begin{tabular}{|c|c|c|c|c|c|c|c|c|c|c|}
\hline & Átlag & Szórás & 1 & 2 & 3 & 4 & 5 & NT/NV & Összesen & Hiányzó \\
\hline \multicolumn{11}{|c|}{ VÁLLALAT „BELSŐ” MARKETINGADATAI } \\
\hline A vállalat saját értékesítési adatai & 4,10 & 1,67 & 14 & 4 & 14 & 75 & 115 & 7 & 229 & 25 \\
\hline A vállalat saját termékeinek piaci ára & 3,60 & 2,45 & 32 & 20 & 16 & 65 & 91 & 8 & 232 & 22 \\
\hline $\begin{array}{l}\text { A vállalat kereskedelmi partnereivel } \\
\text { kapcsolatos információk }\end{array}$ & 3,45 & 1,60 & 14 & 22 & 60 & 78 & 48 & 7 & 229 & 25 \\
\hline $\begin{array}{l}\text { Saját fogyasztókkal/vevókkel } \\
\text { kapcsolatos adatok, információk }\end{array}$ & 3,26 & 1,87 & 30 & 23 & 49 & 84 & 40 & 7 & 233 & 21 \\
\hline \multicolumn{11}{|c|}{ VÁLLALAT „KÜLSŐ” MARKETINGADATAI } \\
\hline \multicolumn{11}{|c|}{ A VÁLLALAT PIACI SZEREPLÉSÉVEL KAPCSOLATOS ADATOK } \\
\hline $\begin{array}{l}\text { A vállalat piacrészesedésére vonatkozó } \\
\text { információk }\end{array}$ & 2,60 & 2,12 & 69 & 46 & 37 & 47 & 29 & 5 & 233 & 21 \\
\hline $\begin{array}{l}\text { A vállalat reklámtevékenységével } \\
\text { kapcsolatos információk }\end{array}$ & 2,36 & 1,87 & 71 & 57 & 42 & 34 & 20 & 8 & 232 & 22 \\
\hline \multicolumn{11}{|c|}{ VERSENYTÁRSAKKAL KAPCSOLATOS ADATOK } \\
\hline $\begin{array}{l}\text { A versenytársak piacrészesedésével } \\
\text { kapcsolatos adatok }\end{array}$ & 2,18 & 1,96 & 94 & 55 & 26 & 29 & 22 & 7 & 232 & 21 \\
\hline A versenytársak termékeinek piaci árai & 2,06 & 1,80 & 101 & 47 & 32 & 28 & 15 & 9 & 232 & 22 \\
\hline A versenytársak értékesítési információi & 1,99 & 1,47 & 97 & 51 & 44 & 22 & 8 & 9 & 231 & 23 \\
\hline $\begin{array}{l}\text { A versenytársak reklámtevékenységével } \\
\text { kapcsolatos információk }\end{array}$ & 1,72 & 1,19 & 119 & 59 & 27 & 10 & 8 & 9 & 232 & 22 \\
\hline
\end{tabular}

Megj.: 1 - egyáltalán nem tartalmazza 5 - teljes mértékben tartalmazza 
gálata során az adatok keletkezési helye alapján tettünk különbséget. A vállalat ügyviteli folyamatai (pl.: értékesítés, számlázás, vevői törzsadatok nyilvántartása stb.) során képződnek a „,belsô” adatok /internal data/. Ezzel szemben tudatos, rendszeres és folyamatos piaci adatgyújjtést igényelnek a vállalat piaci szereplésével, a versenytársakkal, a vevókkel és a piac általános jellemzôivel kapcsolatos „,külsó” adatok /external data/ (Wierenga - van Bruggen, 2000) (4. táblázat).

Eredményeink szerint nagyvállalataink a marketingadatok közül legrészletesebben belsố adatokat tárolnak; elsôsorban a kereskedelemmel és az értékesítéssel kapcsolatos információk hívhatók elô számítógépek segítségével. Ezeket az információkat nem a

5. táblázat

A vizsgált vállalatok

hány százaléka rögzít értékesítési

és marketingadatokat informatikai rendszerek segítségével?

\begin{tabular}{|c|c|c|}
\hline & $\begin{array}{l}\text { Magyar- } \\
\text { ország }^{6}\end{array}$ & $\begin{array}{c}\text { Belgi- } \\
\text { um }\end{array}$ \\
\hline \multicolumn{3}{|c|}{ A VÁLLALAT “BELSŐ” MARKETINGADATAI } \\
\hline A vállalat értékesítési adatai & 94 & 74 \\
\hline A vállalat termékeinek piaci ára & 85 & 86 \\
\hline $\begin{array}{l}\text { A vállalat kereskedelmi partnereivel } \\
\text { kapcsolatos információk }\end{array}$ & 94 & 75 \\
\hline $\begin{array}{l}\text { Fogyasztókkal/vevókkel kapcsolatos } \\
\text { adatok, információk }\end{array}$ & 86 & 94 \\
\hline Átlag & 90 & 82 \\
\hline \multicolumn{3}{|c|}{ A VÁLLALAT „KÜLSŐ” MARKETINGADATAI } \\
\hline \multicolumn{3}{|c|}{$\begin{array}{c}\text { A VÁLLALAT } \\
\text { PIACI SZEREPLÉSÉVEL KAPCSOLATOS ADATOK }\end{array}$} \\
\hline $\begin{array}{l}\text { A vállalat piacrészesedésére vonatkozó } \\
\text { információk }\end{array}$ & 70 & 75 \\
\hline $\begin{array}{l}\text { A vállalat reklámtevékenységével } \\
\text { kapcsolatos információk }\end{array}$ & 68 & 55 \\
\hline Átlag & 69 & 65 \\
\hline \multicolumn{3}{|c|}{ VERSENYTÁRSAKKAL KAPCSOLATOS ADATOK } \\
\hline $\begin{array}{l}\text { A versenytársak piacrészesedésével } \\
\text { kapcsolatos adatok }\end{array}$ & 58 & 39 \\
\hline A versenytársak termékeinek piaci árai & 54 & 25 \\
\hline A versenytársak értékesítési információi & 56 & 7 \\
\hline $\begin{array}{l}\text { A versenytársak reklámtevékenységével } \\
\text { kapcsolatos információk }\end{array}$ & 46 & 10 \\
\hline Átlag & 53 & 20 \\
\hline
\end{tabular}

Megj.: magyar adatok - saját felmérés

belga adatok - Langerak - Commandeur et al. (1998) felmérése, idézi: Wierenga - van Bruggen (2000), 93. old. marketing, hanem más funkcionális részterületek (pl. pénzügy, számvitel ${ }^{5}$ ) munkatársai rögzítik, de az adatokhoz a marketing munkatársai is hozzáférhetnek.

A 4. táblázatból kitúnik, hogy az IT-rendszerek kevesebb külsô, mint belsố marketingadatot tartalmaznak. Ennek nyilvánvalóan az is az oka, hogy a külsố adatok számítógépes rögzítése költséges, mivel szisztematikus piaci adatgyújtést és az adatok vállalati informatikai rendszerekben történő rögzítését teszi szükségessé. A külsô marketinginformációk ráadásul sokszor kvalitatív természetúek (pl. fogyasztói attitúdök stb.), ezért nehezen számszerúsíthetốk és kódolhatók.

Eredményeink szerint a versenytársakkal kapcsolatos információk nem jelennek meg a nagyvállalatok marketinginformatikai rendszerében. A versenytársak termékeinek piaci árait a nagyvállalatok kevesebb, mint 20 százaléka; míg a konkurencia reklámtevékenységéról az adatokat 7-8 százaléka tárolja IT-alkalmazások segítségével.

Adatainkat összevetettük külföldi vizsgálatok eredményeivel is. Langerak, Commandeur et al. (1998) felmérése lehetóséget ad arra, hogy megvizsgáljuk, a magyar és a belga vállalatok milyen mértékben rögzítenek IT-alkalmazások segítségével a marketing szempontjából fontos adatokat (5. táblázat).

Az 5. táblázatból látható, hogy a belga vállalatok a magyar cégekhez hasonlóan fóleg belsố marketingadatokat tárolnak IT-alkalmazások segítségével. A rangsor a három vizsgált információtípusnál megegyezik a belga vállalatok és magyarországi nagyvállalatok esetében. Jelentôsebb eltérést tapasztalhatunk a versenytársakkal kapcsolatos adatok rögzítésének mértékében; ennek okát a két minta eltéró jellegében ${ }^{7}$ látjuk.

\section{Mennyiben fedik le a marketingmenedzsment információs igényeit a nagyvállalatok számítógépes rendszerei?}

Tanulmányunkban a marketingszakemberek által ellátott feladatokból kiindulva elemeztük, hogy az IT-rendszerekben rögzített adatok mennyire fedik le a menedzserek információigényeit. A Dunn\&Humby marketing-tanácsadó cég az angol nagyvállalatok körében 1990-ben végzett vizsgálatából kiderül, hogy a marketingmenedzserek feladatai igen sokrétúek. A válaszadó marketing-szakemberek legalább 80 százaléka megjelölte az alábbi tevékenységeket:

- a versenytársak marketingtevékenységének nyomon követése,

- a vállalat saját termékeinek piaci menedzselése, sikerességük mérése,

- a reklámtevékenység megszervezése,

- piackutatás, 
- a reklám hatékonyságának nyomon követése,

- szegmentáció és célcsoportképzés,

- marketingterv elkészítése,

- részvétel a termékfejlesztésben.

(Idézi: Fletcher, 1995)

Ezek a feladatok jellemzően a vállalat mikrokörnyezetével (vevók, versenytársak, piac) kapcsolatos külsố információkat igényelnek. Wierenga és van Bruggen (2000) szerint a marketingmenedzsmentben a „külső” adatoknak fontosabb szerepük van, mint a „belsô” adatoknak. Kutatásunk eredményei szerint azonban nagyvállalataink informatikai rendszerei nem, vagy csak szórványosan tartalmaznak vevókkel, versenytársakkal kapcsolatos információkat.

A marketingmenedzserek által ellátott feladatok köréból kiindulva tehát megállapíthatjuk, hogy a vállalat ügyviteli folyamatai során képződő belső értékesítési-marketinginformációk a legtöbb vállalatnál nem fedik le a vezetók információigényét. Wierenga és van Bruggen (2000) szerint a belsố adatok dominanciájával jellemezhető marketinginformatikai rendszerek elsősorban a vevốk jelenlegi igényeinek áttekintése, a reklámköltések vizsgálata és az értékesítési tevékenység elemzése során segíthetik információkkal a vezetóket.

\section{A CRM-(Customer Relationship Management) rendszerek}

A Magyarországon kereskedelmi forgalomban kapható integrált vállalatirányítási rendszerek teljes körú vizsgálata ${ }^{8}$ alapján megállapíthatjuk, hogy - kevés kivételtől eltekintve - egyáltalán nem tartalmaznak marketing „,modult”, míg más funkcionális részterületek (pl. pénzügy, számvitel, kontrolling, emberi erőforrás, értékesítés, beszerzés) támogatására kész megoldásokat kínálnak (Keszey, 2003). Ennek okát elsốsorban abban látjuk, hogy nagyon sok magyar vállalat nem végez klasszikus értelemben vett marketinget. Az ezredfordulón a magyar vállalatok mindössze 12 százaléka ${ }^{9}$ rendelkezett önálló marketingosztállyal (Berács - Keszey et al., 2001; Berács, 2003). Míg a marketing súlya ágazatonként, a tulajdonosi struktúra és piaci pozíció függvényében, vagy a vállalat méretétól függóen eltéró lehet, addig a többi vállalati funkció kompetenciájába tartozó feladatok egységesebb képet mutatnak. Integrált informatikai rendszerek segítségével azonban azokat a folyamatokat lehet jól lefedni, amelyek a vállalati és környezeti sajátosságok ellenére is jórészt egységesek és jól programozhatók.

Bár a marketing „fehér folt” a hagyományos vállalatirányítási rendszerek számára, a nagy informatikai rendszerházak felismerték azt a piaci rést, amelyet a fejlett marketingrutinnal rendelkezô, információ-in- tenzív vállalatok marketingmunkájának IT-támogatása rejt magában. A CRM informatikai alkalmazások - amelyek ezt a piaci igényt hivatottak kielégíteni - piaca fiatalnak tekinthetô, hiszen az elsố ilyen rendszerek egy évtizede jelentek meg a piacon.

Egy frissen megjelent felmérés szerint a magyar vezetôk a stratégiai tervezés mögött a második helyen a CRM-et tartják olyan eszköznek, amellyel jelentősen javíthatják vállalatuk eredményességét (Népszabadság, 2006. október 19.). A CRM a vállalatirányítási szoftverek leggyorsabban fejlődő részpiaca, melynek éves forgalmát nyolcmilliárd dollárra becsülik (Figyelő, 2005. szeptember 12.). A CRM az utóbbi 8 év átlagában évente 8,9 százalékos piaci növekedést mutatott, 2008-ban a CRM-rendszerekhez kötődő szolgáltatások értéke várhatóan 11,4 milliárd dollár lesz (van Bruggen - Wierenga, 2005). Ahogy a vállalati gyakorlat oldaláról, úgy az elméleti kutatók részéról is egyre intenzívebb figyelem övezi a témát. A rangos Journal of Marketing folyóirat 2005 októberében az egész számot ennek a témának szentelte, és számos hiánypótló magyar publikáció is napvilágot látott a menedzsmentszakirodalomban az utóbbi években (Mester, 2006; Bokker, 2002; Búdy, 2001).

Winer (2001) szerint a CRM és a világháló használatának terjedése új távlatokat nyitott a vállalatok számára a fogyasztók megismerésében. A CRM-alkalmazások olyan adatbázisokra épülnek, amelyek részletes, a számlázási információkat meghaladó marketingsajátosságokat tárolnak a vevókról (pl. demográfiai jellemzók, a vevő mérete, iparági besorolás ipari vásárlók esetében, hogyan reagált a korábbi ajánlatokra stb.) (Glazer, 1999). A CRM mind operatív, mind stratégiai szinten támogatja a marketingmenedzsmentet, hiszen lehetôséget adnak az adatok sokrétû́ elemzésére és a marketingakciók végrehajtása szempontjából lényeges beszámolók készítésére. Az operatív szintú alkalmazási körbe a napi szintú ügyfél-kapcsolattartás (pl. ügyfélkapcsolat, forródrót, web-ügyfélközpont, reklamációkezelés) informatikai támogatása és az ügyféladatok folyamatos frissítése tartozik (Kamakura - de Rosa et al., 2003). A stratégiai szintú alkalmazás a fogyasztói adatbázisok és az arra épüló elemzési módszerek segítségével eszközt ad az ügyfélérték alapú szegmentálásra, az új termékek keresztértékesítésére, a fogyasztók megszerzésére és megtartására vonatkozó stratégiák kialakítására és végrehajtására (Blattberg - Getz et al., 2001).

Kutatásunkban nagyvállalataink CRM-hez fúződő viszonyát vizsgáltuk: Válaszadóinkat először arra kértük, hogy értékeljék, használnak-e jelenleg valamilyen CRM-jellegú alkalmazást, illetve tervezik-e kiépítését a közeljövőben (2. ábra). 
2. ábra országon. Rigby - Reichheld et al. (2002)

Alkalmaz-e vállalata

az ügyfélkapcsolatok kezelésére kialakított információs technológiai (CRM) rendszert?

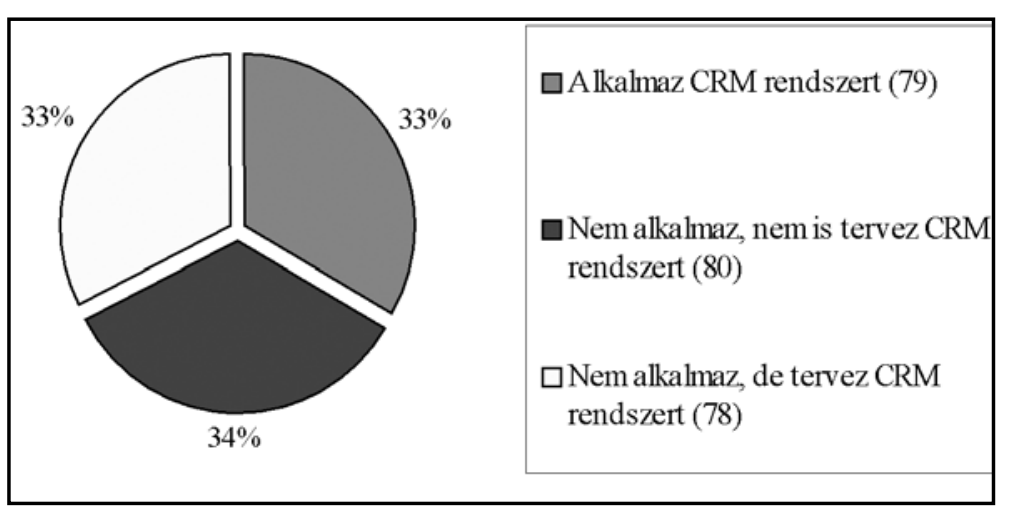

amerikai nagyvállalatok körében végzett felmérése szerint a válaszadók 72 százaléka tervezte egy éven belül CRM-rendszerek kiépítését.

Legnagyobb vállalataink harmadik harmadába olyan cégek tartoznak, amelyek nem rendelkeznek, és nem is tervezik kiépíteni az ügyfél kapcsolatok számítógépes kezelését.

\section{A marketinginformatikai rendszerek észlelt hasznosságát meghatározó tényezók}

Kutatásunkban a legnagyobb árbevétellel rendelkezô magyar vállalatok körében azt is vizsgáltuk, hogy milyen tényezók határozzák

Nagyvállalataink CRM-hez füződő viszonyuk alapján három egyforma méretú csoportba sorolhatók.

A cégek egyharmada már alkalmaz az ügyfélkapcsolatok kezelésére valamilyen informatikai rendszert. Itt további kérdésekkel pontosítottuk, hogy milyen rendszerról van szó. A kereskedelmi forgalomban kapható piacvezető CRM-rendszerek (SAP CRM, Oracle CRM, Siebel, Remedy) valamelyikét válaszadóink 13 százaléka használta a marketingmunkában (3. ábra), ezek közül méréseink szerint az SAP a piacvezetố. Ez az eredmény párhuzamba állítható Bokker (2002) ténymegállapításaival. Bokker (2002) szintén nagyvállalatokat vizsgálva azt találta, hogy 14 százalékuk használ jelenleg CRM-rendszereket (ami az integrált vállalatirányítási rendszerek 55 százalékos elterjedtségéhez képest alacsonynak tekinthetó ebben a vállalati körben). A legtöbb vállalat saját fejlesztésú rendszert alkalmaz az ügyfélkapcsolatok menedzselésénél, míg a vállalatok egyötöde kisebb, kereskedelmi forgalomban kapható alkalmazások segítségével tartja a kapcsolatot ügyfeleivel.

A második csoportba azok a vállalatok tartoznak, amelyek ugyan még nem vettek alkalmazásba ilyen informatikai rendszereket, de ezt a közeljövóben tervezik. Bokker (2002) hasonló vállalati körben végzett korábbi kutatási eredményei szerint is fontos prioritásnak tekintik a vállalatvezetốk a CRMrendszerek kialakítását Magyarmeg leginkább, mennyire érzik a marketingszakemberek saját mindennapi munkájuk során hasznos és fontos eszköznek az információtechnológiai alkalmazásokat.

Az IT-rendszer marketingben betöltött szerepét 6 állítás segítségével mértük. Ötfokozatú, Likert-típusú skála alkalmazásával számszerúsítettuik, mennyire érzik úgy a vezetók, hogy az IT-rendszerekkel jobb döntéseket tudnak hozni, mennyire könnyíti meg, és mennyire gyorsítja fel a marketingmunkát a számítástechnika, milyen gyakran használja az IT-rendszert a vezetô, menynyire ítéli hasznosnak saját munkája szempontjából, és összességében mekkora hatással van a marketingmunkára. A válaszadókat arra kértük, azokra a vállalaton

Milyen típusú CRM-rendszert alkalmaz 3. ábra az Ön vállalata?

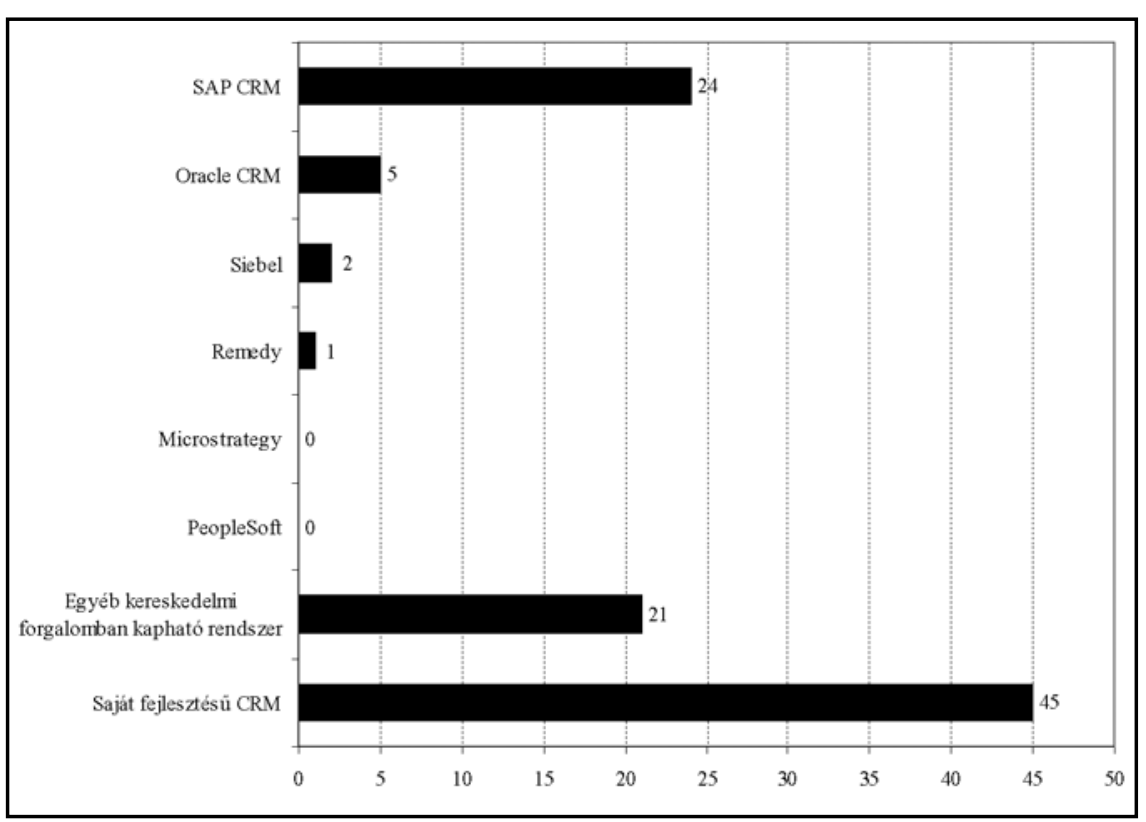


belül használt információtechnológiai alkalmazásokra gondoljanak, amelyek tartalmuk (marketingadatokat tartalmaznak), vagy funkciójuk (pl. a marketingterv vagy szegmentálás kialakításánál támaszkodnak rá) alapján kötődnek a marketingmunkához.

\section{Az IT-rendszerek marketingmenedzsmentben betöltött szerepét meghatározó tényezôk}

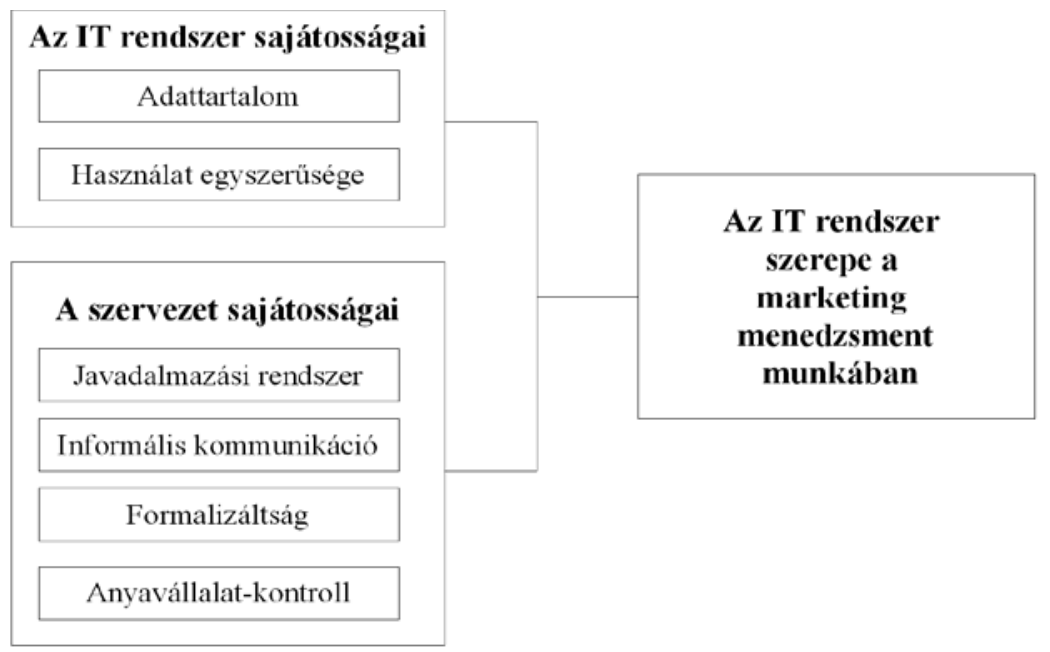

A 4. ábrán bemutatott modellünket lineáris regresszióelemzés segítségével teszteltük (ld. 6. táblázat). A determinációs együttható ( $R$ négyzet) értéke 0,36 . A vizsgálatba bevont független változók tehát együttesen 36 százalékban magyarázzák a nagyválla-

4. ábra latok marketingtevékenységében az ITrendszerek fontosságának átlagtól való eltéréseit. A vizsgált független változók közül fontossági sorrendben a rendszer használatának egyszerúsége, a tárolt marketingadatok mélysége, a javadalmazási rendszer teljesítményfüggő́sége, a marketing- és értékesítési kollégák közötti kommunikáció mértéke, a külföldi anyavállalat magyar leányvállalatra gyakorolt hatása és a vállalat formalizáltságának mértéke határozza meg leginkább, hogy a marketingmenedzsment-munkában mennyire bizonyulnak hasznos és fontos eszköznek a számítógépes alkalmazások.

A következókben részletesen áttekintjük valamennyi változót, és a témakör nemzetközi szakirodalma alapján megvilágítjuk az összefüggéseket.
A vizsgálat során (ld. modell a 4. ábrán) arra voltunk kíváncsiak, hogy a szervezet és az informatikai rendszer sajátosságai milyen mértékben határozzák meg az informatikai rendszer észlelt hasznosságát.

A regresszióelemzés eredményei

6. táblázat

\begin{tabular}{|l|c|c|}
\hline & $\begin{array}{c}\text { Stenderdizált } \\
\text { Béta-koefficiens }\end{array}$ & t-érték \\
\hline Konstans Az IT-rendszer sajátosságai \\
\hline \multicolumn{2}{|c|}{,- 55} \\
\hline $\begin{array}{l}\text { Adattartalom (Az IT-rendszerben } \\
\text { tárolt adatok köre és mélysége) }\end{array}$ &, 25 & $3,29 * *$ \\
\hline $\begin{array}{l}\text { Használat egyszerúsége (Mennyire } \\
\text { „felhasználóbarát" a rendszer?) }\end{array}$ &, 38 & $5,04 * * *$ \\
\hline \multicolumn{2}{|c|}{ A szervezet sajátosságai } \\
\hline $\begin{array}{l}\text { Javadalmazási rendszer (Milyen } \\
\text { mértékben függ a teljesítménytól } \\
\text { a javadalmazási rendszer?) }\end{array}$ &, 27 & $3,64 * * *$ \\
\hline $\begin{array}{l}\text { Informális kommunikáció (Milyen } \\
\text { élénk a marketing- és értékesítési rész- } \\
\text { legek közötti információ megoszlás?) }\end{array}$ &, 23 & $3,04 * *$ \\
\hline Formalizáltság &, 17 & $2,35^{*}$ \\
\hline Anyavállalat-kontroll &, 18 & $2,40^{*}$ \\
\hline Teljes R négyzet = ,36 F = 10,215*** & & \\
\hline
\end{tabular}

$* \mathrm{p}<, 05 * * \mathrm{p}<, 01 * * * \mathrm{p}<, 001$

\section{Adattartalom}

Kutatásunkban hat állítás segítségével vizsgáltuk az IT-rendszerekben rögzített marketingadatok körét és részletességét. A marketingadatok alatt kereskedelmi, piaci teljesítményre és a versenytársakra vonatkozó információkat értettünk. Eredményeink minél több releváns marketingadatot tartalmaz az IT-rendszer, annál jobbnak és hasznosabbnak fogják tartani. Vizsgáltuk, hogy milyen információk tárolása járul leginkább ahhoz, hogy a vezetốk hasznosnak tartsák a rendszert (7. táblázat).

7. táblázat

A marketing-informatikai rendszerekben tárolt adatok típusa és észlelt hasznossága közötti összefüggések

\begin{tabular}{|l|c|c|c|c|}
\hline & $\begin{array}{c}\text { IT- rend- } \\
\text { szer meg- } \\
\text { ítélése }\end{array}$ & $\begin{array}{c}\text { Keres- } \\
\text { kedelmi } \\
\text { adatok }\end{array}$ & $\begin{array}{c}\text { Piaci tel- } \\
\text { jesítmény- } \\
\text { adatok }\end{array}$ & $\begin{array}{c}\text { Verseny- } \\
\text { társak } \\
\text { adatai }\end{array}$ \\
\hline $\begin{array}{l}\text { IT-rendszer } \\
\text { megítélése }\end{array}$ & 1,00 & 1,00 & & \\
\hline $\begin{array}{l}\text { Kereskedelmi } \\
\text { adatok }\end{array}$ &, $513 * * *$ & 1,00 & \\
\hline $\begin{array}{l}\text { Piaci teljesít- } \\
\text { mény-adatok }\end{array}$ &, $381 * *$ &, $456^{* *}$ &, $740 * * *$ & 1,00 \\
\hline $\begin{array}{l}\text { Versenytársak } \\
\text { adatai }\end{array}$ &, $299 * *$ &, $356^{* *}$ &, 00 \\
\hline
\end{tabular}

Megj.: ${ }^{*} \mathrm{p}<, 05 * * \mathrm{p}<, 01 * * * \mathrm{p}<, 001$ 
Eredményeink szerint az információs rendszer megítélését leginkább az IT-alkalmazásokban rögzített kereskedelmi adatok mennyisége magyarázza. Minél részletesebben tartalmazza a marketing-információrendszer a vállalat saját termékeinek áradatait, az értékesítési vagy a kereskedelmi partnerekre vonatkozó adatokat, annál hasznosabbnak fogják tartani a vezetôk az IT-alkalmazásokat.

Megpróbáltuk feltárni, hogy miért épp a szoftverben tárolt kereskedelmi adatok mennyisége határozza meg leginkább, hogy mennyire használja azt a vezetố munkája során. Ehhez áttekintettük a marketing- és értékesítési funkciók egymáshoz viszonyított relatív súlyát a magyar vállalatoknál. Megnéztük, vállalatainknál melyik jellemzóbb inkább: a marketingfunkció alá sorolják-e be az értékesítést, vagy fordítva, az értékesítés részét képzi-e a marketing (8. táblázat).

8. táblázat

A marketing

és értékesítési részlegek szervezeti elhelyezkedése a magyar vállalatoknál

\begin{tabular}{|c|c|c|c|c|}
\hline Szervezeti megoldás & $\begin{array}{c}\mathbf{1 9 9 2} \\
(\mathbf{n = 8 9 3})\end{array}$ & $\begin{array}{c}\mathbf{1 9 9 6} \\
(\mathbf{n = 5 8 9})\end{array}$ & $\begin{array}{c}\mathbf{2 0 0 0} \\
(\mathbf{n = 5 7 2})\end{array}$ & $\begin{array}{c}\mathbf{2 0 0 3} \\
(\mathbf{n = 2 8 9})\end{array}$ \\
\hline $\begin{array}{l}\text { A marketing az értékesítési/ } \\
\text { kereskedelmi osztály része }\end{array}$ & 27 & 35 & 35 & 42 \\
\hline $\begin{array}{l}\text { Az értékesítés a marketing- } \\
\text { osztály része }\end{array}$ & 14 & 10 & 13 & 14 \\
\hline
\end{tabular}

Megj.: 2003-ban kizárólag nagyvállalatok körében vizsgálódtunk, a korábbi felmérések a 20 fónél több alkalmazottat foglalkoztató magyar vállalatok körében készülttek.

A 8. táblázatból kitúnik, hogy a magyar vállalatoknál gyakoribb, hogy a marketingfunkció az értékesítési osztály ,alá” tartozik; ami az értékesítés marketingfunkcióval - és talán marketingorientációval ${ }^{10}$ - szembeni dominanciájára utal.

Összességében azt gondoljuk, hogy az IT-rendszerekben tárolt kereskedelmi-értékesítési adatok mélysége azért járul hozzá nagyobb mértékben az alkalmazás hasznosságérzetéhez, mint a piaci-versenytárs adatoké, mert vállalataink többsége az értékesítési funkciót fontosabbnak tartja a marketingfunkciónál - legalábbis ez derül ki vállalataink szervezeti felépítéséból. Másrészt a kereskedelmi adatok könnyebben algoritmizálhatók, és így IT-rendszerek segítségével könnyebben tárolhatók, mint a ,szoft” külsó piaci adatok, így feltételezhetjük, hogy a marketingmenedzserek a számítógépes alkalmazásokon kívüli forrásoknak nagyobb súlyt adnak a versenytársakkal vagy épp a vállalat piaci teljesítményével kapcsolatos tájékozódás során.

\section{A használat egyszerǘsége}

A használat egyszerúsége faktort három állítás segítségével mértük. Megkérdeztük, hogy mennyire tartja egyszerúnek a menedzser a szoftver használatát, mennyire képes önállóan, más kollégák segítsége nélkül lekérni az információkat, és milyen mélységú felhasználói képzésben részesült.

Eredményeink szerint a marketinginformatikai alkalmazások szerepéról kialakított véleményt leginkább ez a faktor határozza meg. A marketingvezetók kiterjedtebben használják azokat a rendszereket, amelyekból az információkat saját maguk más kollégák (pl. asszisztensek, adatbázisok kezelésére szakosodott kollégák, informatikusok stb.) segítsége nélkül tudják lekérdezni. Minél kiterjedtebb képzésben részesültek a marketingvezetők az informatikai alkalmazás használatba vétele eloott, annál fontosabb szerepet játszik a rendszer a menedzsmentmunkában.

A rendszer egyszerú használata nagyobb mértékben járul hozzá az alkalmazás hasznosságának megítéléséhez, mint a rendszerben tárolt adatok mennyisége és köre (ld. magasabb t- és standardizált béta koefficiens érték a könnyư rendszerhasználat, mint a rendszer adattartalma faktornál). Az informatikai rendszerek vezetői megítélése szempontjából tehát fontosabb a könnyú, felhasználóbarát alkalmazhatóság, mint az, hogy menynyi marketingadatot tárol a rendszer. Ahhoz, hogy egy informatikai alkalmazás támogassa a vezetók munkáját nem elegendő a szükséges adatok rögzítését biztosítani, ennél fontosabb, hogy a menedzserek elsajátítsák a munkájukhoz szükséges felhasználói ismereteket.

A témakör nemzetközi szakirodalmában is találunk kutatási eredményeinkkel párhuzamba állítható megállapításokat. Az új információs rendszerek vezetói elfogadásában és folyamatos használatában meghatározó szerepe van annak, hogy mennyire „felhasználóbarát” az alkalmazás (Venkatesh, 2000). Davis (1989) szerint az egyszerú rendszerhasználat pozitívan befolyásolja a vezetô IT-alkalmazásokkal kapcsolatos attitúdjét. Fontos, hogy a marketingvezetók az IT-rendszer használatba vétele előtt megfelelő tréningben részesüljenek (Alavi - Joachimsthaler, 1992), ha ez elmarad, hiába fordít a vállalat jelentôs eróforrásokat az informatikai rendszerek kialakítására, a vezetők nem fogják tudni használni azt. Leonard-Barton és Deschamps (1988) hasonló következtetésre jutott: annál kiterjedtebben használják a menedzserek az informatikai alkalmazásokat, minél alaposabb felhasználói képzésben részesültek. Adams - Berner et al. (2004) szerint az IT-rendszerek felhasználóinak képzése a kulcs az új informatikai rendszerek birtokba vételével kapcsolatos ellenérzések leküzdése során. A CRM rendszereket vizsgálva van Bruggen és 
Wierenga (2005) azt találta, hogy annál hasznosabbnak vélik a marketingvezetók az IT alkalmazásokat, minél könnyebben tudják használni azt.

A felhasználói tréningek sikeressége nyilván nem függetleníthetố attól, hogy milyen a szakemberek informatikai „elóképzettsége”. Gross - Hartley et al. (1999) 300 magyar és 700 amerikai menedzser összevetése alapján azt állapította meg, hogy a magyarok tehetséges, analitikus gondolkodású, kissé körülményes vezetốknek tûnnek, akiknek amerikai kollégáikhoz képest az informatikai rendszerek használata területén komoly lemaradásaik vannak. Zoltay - Paprika (2002) szintén arra mutat rá, hogy a magyar menedzserek saját, vezetéshez kötődő képességeik közül az IT-tudást (PC-alkalmazást) értékelik a legalacsonyabban.

Mivel saját kutatásunk eredményei és a nemzetközi szakirodalom alapján is fontos szerepe van az ITrendszerek vezetôi megítélésben annak, hogy mennyire könnyư használni alaposabban is górcső alá vettük ezt a tényezőt. Megvizsgáltuk, hogy a magyar nagyvállalatoknál használt informatikai alkalmazások funkciói és múködése mennyiben felel meg a marketingvezetôk elvárásainak (9. táblázat). hatékonyabbá tételével kapcsolatos lehetőségeket. Az eredmények tehát heterogén képet mutatnak; mindenesetre örvendetes, hogy a leggyakoribb válasz (módusz) arra utal, hogy a marketingvezetók beleszólhatnak az informatikai alkalmazások kiépítésébe.

Kutatásunkban vizsgáltuk, hogy a marketingvezető́k részesültek-e olyan képzésben, ahol elsajátíthatták az IT-rendszer alkalmazását. A megkérdezett marketingmenedzserek közel ötven százaléka adott egyértelmúen pozitív választ a kérdésre. Elgondolkodtató azonban, hogy menedzsereink közel harminc százaléka számolt be arról, hogy nem vagy alig részesült megfelelô felhasználói képzésben.

Két állítást fogalmaztunk meg azzal kapcsolatosan, hogy mennyire „felhasználóbarát” az IT-rendszer. Az első kérdés arra vonatkozott, hogy a munkája szempontjából fontos beszámolók elkészítését segíti-e a számítógép, a második pedig arra, hogy a vezetô által igényelt formátumban ,adja-e ki” az alkalmazás a kért riportokat. Eredményeink szerint nagyvállalataink marketingvezetôinek többsége olyan IT-alkalmazásokkal dolgozik, amelyek tartalmazzák a számukra fontos adatokat. A vezetốk 13 százaléka azonban úgy véli,

9. táblázat

A marketinginformatikai rendszerek múködésének vezetői megítélése

\begin{tabular}{|l|c|c|c|c|c|c|c|c|c|c|}
\hline & Átlag & Szórás & $\mathbf{1}$ & $\mathbf{2}$ & $\mathbf{3}$ & $\mathbf{4}$ & $\mathbf{5}$ & NT/NV & Összesen & Hiányzó \\
\hline $\begin{array}{l}\text { A rendszer kialakításában } \\
\text { részt vettem }\end{array}$ & 2,89 & 1,43 & 56 & 42 & 40 & 68 & 34 & 3 & 243 & 17 \\
\hline $\begin{array}{l}\text { A program használata elótt teljes körú } \\
\text { képzésben részesültem }\end{array}$ & 3,10 & 1,28 & 18 & 54 & 45 & 93 & 24 & 9 & 243 & 17 \\
\hline $\begin{array}{l}\text { Számomora fontos beszámolókat nem } \\
\text { tudok a rendszerból lekérni }\end{array}$ & 2,38 & 1,00 & 28 & 106 & 66 & 26 & 5 & 7 & 238 & 22 \\
\hline $\begin{array}{l}\text { A rendszerból letöltött adatokat, beszámo- } \\
\text { lókat a felhasználáshoz át kell alakítani }\end{array}$ & 3,02 & 1,17 & 13 & 62 & 75 & 61 & 25 & 6 & 242 & 18 \\
\hline
\end{tabular}

Megj.: 1 - egyáltalán nem jellemző 5 - teljes mértékben jellemző

Az eredmények alapján nehéz markáns véleményt megfogalmazni azzal kapcsolatosan, hogy a marketingszakemberek mennyire vesznek részt az informatikai alkalmazások kialakításában. A 9. táblázat elsố sorából látható, hogy megközelítőleg ugyanannyi vállalatnál voltak a „marketingesek” az IT-rendszer kialakításának aktív részesei, mint ahány vállalatnál nem kérték ki véleményüket. Egy informatikai rendszer kialakítására nyilvánvalóan nem lehet úgy tekinteni, mint szúk értelemben vett technikai kérdésre. Ha egy vállalatnál nem kérik ki az üzleti háttérrel rendelkezô, a vállalati folyamatokat jól ismeró gazdasági szakemberek véleményét, akkor kérdéses, hogy a felsô vezetók felismerik-e az IT-rendszerekben rejlő, az értékteremtô folyamatok hogy nem vagy egyáltalán nem éri el az elvárt információkat a számítógépeken keresztuil.

A 236 érvényes választ adó marketingvezető közül csupán 13 (5,5 százalék), kap „gombnyomásra” olyan beszámolókat, amelyeket a további munkához már nem kell átalakítani. A lehívott adatokat tehát a magyar marketingvezetốk 95 százalékának át kell alakítania, mert felépítése vagy részletezettsége nem felel meg igényeinek.

Ez az eredmény fel kell, hogy keltse az informatikai fejlesztésekért felelős vezetốk figyelmét. Az IT rendszerek hasznosságának érzetéhez jelentôsen hozzájárul, hogy mennyire támogatja az alkalmazás közvetlenül is a munkát, ezért fontos azok használatát monitorozni, folyamatosan nyomon követni. Ez fényt deríthet olyan kisebb fejlesztési igényekre, amilyen például a beszámolók formátumának megváltoztatása. Egy ilyen ap- 
róbb változtatás - miközben egy IT-rendszer kiépítéséhez képest marginális ráfordításokkal megvalósítható - megkönnyítheti a menedzserek munkáját.

\section{Javadalmazási rendszer}

A javadalmazási rendszer vizsgálata során arra voltunk kíváncsiak, milyen mértékben függ a vezetők javadalmazása a vállalat teljesítményétől. A faktort 4 változó segítségével mértük. Vezetőink ötfokozatú, szemantikus differenciálskálán értékelték, hogy javadalmazásuk milyen mértékben múlik más részlegek teljesítményéhez való hozzájárulásukon, beosztottjainak, munkatársainak, munkacsoportjának, üzletágának, illetve vállalatának teljesítményén.

Eredményeink szerint, minél nagyobb szerepet kap a marketingvezetók javadalmazásában a teljesítmény szerepe, annál fontosabb és hasznosabb eszköznek fogják tartani az informatikai alkalmazásokat. Láthattuk a 4. táblázatban, hogy nagyvállalataink informatikai rendszerei leginkább kereskedelmi-értékesítési adatokat tartalmaznak. A marketingmenedzserek tehát az informatikai alkalmazások segítségével gyorsan nagy mennyiségú információhoz juthatnak arra vonatkozóan, hogy például mennyi volt az elmúlt idôszakban a vállalat értékesítése, milyen területi eltérések tapasztalhatók; az értékesítési partnerek milyen értékben vásárolták a vállalat termékeit. Kérdés, hogy ezek az információk mennyiben fontosak és hasznosak az olyan vállalatvezetốk részére, akik teljesítményarányosan kapják jövedelmüket, vagy úgy is feltehetjük a kérdést, hogy miért érzik hasznosabbnak az IT-rendszerben rögzített kereskedelmi adatokat azok a vezetók, akiknek a fizetésük a vállalat piaci szereplésétôl is függ.

Ahhoz, hogy választ tudjunk adni a kérdésre, azt kell megértünk, hogy a vállalatvezetók szerint mit jelent a piaci teljesítmény fogalma, illetve a piaci teljesítmény mérésében milyen szerepet kapnak az értékesítésre vonatkozó visszajelzések.

Berács (2003) kutatásában vizsgálja a magyar marketingvezetôk által az ezredfordulón legfontosabbnak tartott piaci teljesítménymutatókat. Berács (2003) szerint az öt legfontosabb teljesítmény-mutatószám 2000ben fontossági sorrendben a következő volt:

1. realizált profit,

2. fogyasztói elégedettség,

3. tókemegtérülés,

4. eladási volumen,

5. haszonkulcs.

Láthatjuk, hogy a marketinginformatikai alkalmazások ezek közül szinte „,gombnyomásra” képesek visszajelzést adni az eladási volumenre vonatkozóan. Azért érzik tehát hasznosabbnak azok a menedzserek az informatikai rendszereket, akiknek a javadalmazásuk a piaci teljesítményen is múlik, mert az IT-alkalmazások gyorsan, pontosan és nagy mennyiségben képesek kereskedelmi-értékesítési információkat szolgáltatni, miközben ezek az információk a vállalat piaci teljesítményének fontos mérôszámai.

Van Bruggen és Wierenga (2005) szerint a vállalatvezetốk annál fontosabbnak tartják a CRM-rendszereket, minél nagyobb súlyt kap javadalmazásukban a fogyasztóközpontú hozzáállás. Van Bruggen és Wierenga (2005) szerint a CRM-rendszerek - mivel lehetôséget biztosítanak a fogyasztókkal való kapcsolattartásra és számos fogyasztói adatot tartalmaznak - fontos információkkal segíthetik a marketingmenedzsereket abban, hogy vevőiket jobban kiszolgálják - miközben a vezetók a motivációs rendszeren keresztül épp ebben érdekeltek. Day (2003) szintén rámutat a megfelelő érdekeltségi rendszer kulcsfontosságú szerepére a munkatársak vevőorientált magatartásának megteremtésében.

Az eredmények alapján azt mondhatjuk, hogy a marketingmenedzsment-tevékenységet támogató ITalkalmazásokat nagyobb mértékben használják, és fontosabbnak tartják a vezetők, ha azok olyan információkat képesek nyújtani, amelyek nyomon követésében és felhasználásában érdekeltek. Tehát nem elegendő a menedzsmentmunka szempontjából releváns adatokkal „,feltölteni” az IT-rendszert, de a motivációs rendszert is úgy kell kialakítani, hogy fontosnak tartsák ezeknek az információknak a felhasználását a vezetôk, csak így lehet az informatika a marketingmenedzsment támogatásának hatékony eszköze.

\section{Az informális kommunikáció}

Az informális kommunikáció faktor mérésénél három állítást vizsgáltunk, hogy mennyire közöl fontos és mennyire a munkához közvetlenül kapcsolódó piaci információkat az értékesítésen dolgozó kolléga, valamint hogy mindig idóben értesítik az értékesítést végzó munkatársak a piaci eseményekról a marketingmenedzsereket.

Eredményeink szerint minél szorosabb az értékesítésen dolgozó kollégák és a marketingmenedzserek között a munkakapcsolat - a sales területen dolgozó szakemberek folyamatosan és időben tájékoztatják a marketing-döntéshozókat a piaci fejleményekról -, annál hasznosabbnak fogják tartani a marketingvezetôk az informatikai rendszereket. A marketing és értékesítés területén dolgozó szakemberek közötti információ megosztás tehát hozzájárul ahhoz, hogy az IT-rendszerekben rögzített adatok is nagyobb mértékben épüljenek be a marketingmunkába. 
A kereskedelmi munkatársaktól kapott, sokszor informális csatornákon keresztül megosztott információk segíthetik a marketingvezetóket abban, hogy az IT-rendszerekben rögzített „száraz”, tényszerú, kvantitatív adatokat értelmezzék, kontextusba helyezzék. Mivel az értékesítési munkatársak közvetlen kapcsolatban vannak a vevőkkel, képesek naprakész információkkal és véleményekkel segíteni a marketingvezetőket, akik így nemcsak könnyebben tudják az IT-rendszerekből kinyerhetô tényadatokat értelmezni, de hasznosabbnak is tartják ezeket a számítógépes alkalmazásokat.

Fontos következtetés, hogy az informális információ megosztás (folyosói beszélgetések, piaci pletykák stb.) segíti a sokkal nagyobb anyagi ráfordítások árán megszerezhetố, formális csatornákon keresztül áramló információk értelmezését és felhasználását. A hagyományos menedzsment felfogásban az informális beszélgetéseket nem tekintették az érdemi munka részének, ezért sok helyen direktívák útján tiltották. Napjainkban ezzel szemben kezdik felismerni ennek jelentőségét, ezt példázza az is, hogy nagyvállalataink 30 százaléka szervez olyan rekreációs és sporteseményeket, amelyek „közelebb hozzák” egymáshoz a munkatársakat. Az újonc munkatársak „betanítása” során egyre több vállalat követi az ún. ,job-rotation" megközelítést, amelynek célja, hogy a dolgozók a saját szúkebb szakterületükön kívül más részlegek munkájába is belelássanak. A személyes, szúk értelemben vett munkakapcsolaton túlmutató ismeretség, és az egymás szakterületére való ,rálátás” segíti a munkatársakat a nyílt, informális kommunikációban is.

A marketing és más részlegek munkatársainak kapcsolatát több korábbi kutatás is vizsgálta, azonban ezek a kutatások leginkább az együttmúködés szorosságát és nem formális vagy informális voltát vették górcsố alá. Kivétel ez alól Maltz és Kohli (1996), aki marketing- és nem marketing (gyártási, $\mathrm{K}+\mathrm{F}$ és pénzügyi) menedzserek között vizsgálta az információmegosztás módját (mennyire formális az). Eredményeik szerint annál érthetőbbnek tartják a marketingvezetők a más részlegektól kapott piaci információkat, minél kiegyensúlyozottabb a formális és informális csatornák használata - vagyis ideális esetben a formális kommunikációt (pl. beszámolók, riportok) kiegészítik az informális tájékoztatások (pl. ad-hoc telefonbeszélgetések).

Deshpandé és Zaltman (1982), valamint Moorman - Zaltman et al. (1992) a piackutatók és a marketingmenedzserek közötti együttmúködést vizsgálva arra jutottak, hogy a piackutatások annál fontosabb szerepet játszanak a marketing-döntéshozatalban, minél többet találkoznak a projekt során a vezetốk és a kutatók.

\section{Formalizáltság}

A munkakör formalizáltsága alatt azt értjük, hogy a marketingszakembereknek mennyire kell leírt szabályok alapján körülhatárolt feladatkörben dolgozniuk. Eredményeink szerint minél több direktíva írja körül a marketingvezetố által ellátandó feladatokat, annál nagyobb mértékben fog munkája során az informatikai rendszerekre támaszkodni. Eredményeink tehát arra engednek következtetni, hogy a formalizáltság egyfajta rendet, rutint és szigort visz a marketingmenedzsment munkájába, amelynek hatására kisebb mértékben „sikkadnak el" a rendelkezésre álló, számítógépekben tárolt információk.

Több korábbi kutatás is vizsgálta, hogyan hat a marketing-információrendszer múködésére a munkakör formalizáltsága. Zaltman - Duncan et al. (1973) innovációval kapcsolatos kutatásai szerint a formális rutinok szerint múködő vállalatok innovációs képessége elmarad az informálisabb alapon szerveződő vállalatokétól. Ez az eredmény nem mond feltétlenül ellent kutatási eredményeinknek. Az innováció minden esetben valamilyen újszerú, a korábbitól eltérô termék vagy folyamat megvalósítását célozza; amelynek az írásban rögzített szabályok, direktívák nem kedveznek. Ezzel szemben a formalizáltság épp a rögzült rutinokon keresztül pozitívan hat az IT-rendszerben rögzített - a marketingvezetốk többsége által nem túl fontosnak tartott - adatok nyomon követésére. John and Martin (1984) a marketingtervek megvalósítását vizsgálva arra jutott, hogy a formalizáltabb vállalatok általában következetesebben „végigviszik” a tervben lefektetett programjukat. Low és Mohr (2001) szerint a formalizáltabb vállalatok több információt vesznek figyelembe marketingkommunikációs tevékenységük értékelése során, mint lazább, informálisabb versenytársaik. Keszey (2004) szerint nagyobb mértékben támaszkodnak a piackutatásokra azok a menedzserek, akiknek munkaköre írásban szabályozott, rögzített.

A szakirodalmi referenciák és kutatásunk eredményei alapján úgy túnik, hogy a formalizáltság hatására a vezetók szélesebb körú információk alapján tájékozódnak, ugyanakkor elbátortalanítja a menedzsereket abban, hogy súlyozzanak az információforrások között, és eldöntsék, melyek a fontos és melyek a lényegtelen adatok.

\section{Az anyavállalat-kontroll}

$\mathrm{Az}$ anyavállalattal való kapcsolat szorosságát kutatásunkban négy változó segítségével mértük. Kérdéseket fogalmaztunk meg arra vonatkozóan, hogy a kulcspozícióban külföldi szakemberek dolgoznak-e, mekkora a leányvállalat szabadságfoka a marketingstratégia kialakításában, mennyire kell alátámasztani 
a döntéseket, ha azok ellentétesek az anyavállalat javaslataival, illetve mennyire formálta „saját képére” az anyavállalat a leányvállalatot.

Eredményeink szerint minél „rövidebb pórázon” tartja a külföldi anyavállalat a magyar leányvállalatot, annál fontosabb szerepet kapnak a számítógépes alkalmazások a marketingmenedzsmentben. A kérdés tehát az, hogy miért használják kiterjedtebben az IT-rendszereket azoknál a vállalatoknál, ahol a kulcspozíciókban külföldiek ülnek, a marketingkoncepciót a külföldi központban dolgozták ki, Magyarországon csak mechanikusan végre kell hajtani, az anyavállalat a saját képére formálta a vállalatot, vagy épp nagyon meg kell indokolni valamit, ha nem az anyavállalat javaslatait fogadják el. A kérdés megválaszolásához a marketingmenedzsment-tevékenységet támogató informatikai rendszerek szakirodalmi diskurzusa kevés fogódzót kínál, mivel a korábbi empirikus kutatások - jórészt mert az amerikai piacokon épp az ,,anyavállalatoknál” vizsgálódtak - ezt az összefüggést nem tárták föl.

Jelen tanulmány is csupán felszínes betekintést enged a marketing-információrendszer múködése és a vállalati autonómia összefüggésébe, és nyilvánvalóan további vizsgálatok szükségesek a jelenség feltárásához, azonban érdekes lehet az okokon eltúnődni. Az informatikai rendszerek alkalmazása szükségszerúen növeli a múködés átláthatóságát, transzparenciáját - ez nyilvánvalóan fontos szempont egy olyan külföldi tulajdonos számára, amely a kulcspozíciókba külföldi szakemberek delegálásával is folyamatosan kontrollálni szeretné a leányvállalat munkáját, teljesítményét. A vállalat központi standardjainak mechanikus átvételével fontosabbá válik a menedzsmentmunkában az informatika, miközben a menedzserek többsége úgy gondolja, hogy a piaci tájékozódásban a számítógépek nem hatékonyak.

\section{A kutatás módszertana}

\section{A méröeszköz (kérdốiv) kialakitása, tesztelése}

A kutatásban alkalmazott méróeszközt több etapban végzett tesztelések során véglegesítettuik (Curchill, 1979). A kérdőív elsố változatának kialakításánál egyrészt támaszkodtunk a témakör szakirodalmában fellelhetô, korábban alkalmazott - és a fóleg amerikai üzleti környezetben megbízhatónak bizonyult - skálákra, illetve a felmérést megelőző mélyinterjúk során felmerült szempontok alapján a kutatásban használtunk saját fejlesztésú állításokat is. A mérőeszközt két lépésben teszteltük. Először két akadémiai szakembert kértünk a kérdőív elsố változatának tartalmi, illetve formai értékelésére. A tesztelés második fázisában marketingszakirányos, MBA-hallgatókkal töltettük ki pilot-jellegúen a kérdő́ivet (10. táblázat).

10. táblázat

\section{A kutatásban alkalmazott skálák alapstatisztikái és összefüggései}

\begin{tabular}{|l|c|c|c|c|c|c|c|c|c|c|c|c|c|c|c|}
\hline \multicolumn{1}{|c|}{ Alkalmazott skála } & $\begin{array}{c}\text { Tételek } \\
\text { száma }\end{array}$ & $\begin{array}{c}\text { Terje- } \\
\text { delem }\end{array}$ & Átlag & $\begin{array}{c}\text { Szó- } \\
\text { rás }\end{array}$ & $\begin{array}{c}\text { Cronbach } \\
\text { Alpha }\end{array}$ & $\mathbf{1}$ & $\mathbf{2}$ & $\mathbf{3}$ & $\mathbf{4}$ & $\mathbf{5}$ & $\mathbf{7}$ & $\mathbf{8}$ \\
\hline \multicolumn{7}{|c|}{ Függó változó } & & \\
\hline Az IT-rendszer észlelt hasznossága & 6 & $1-5$ & 3,63 & 1,16 &, 92 & 1 & & & & \\
\hline
\end{tabular}




\section{Az adatfelvétel}

A felmérés 2003 nyarán történt az OTKA támogatásával és a Központi Statisztikai Hivatal (KSH) Cégkódtár 2003/I. negyedéves kiadványán, mint mintavételi kereten alapul. A 972 nagyvállalatot ${ }^{11}$ tartalmazó potenciális mintából végül 254 választ kaptunk, mely 26 százalékos válaszadási aránynak felel meg. Adatainkat önkitöltős kérdőív segítségével gyújtöttuik, amelyet postai úton juttattunk el válaszadóinknak. A levelek postai kiküldését megelôzôen a vállalatok egy részével e-mailen keresztül vettük fel a kapcsolatot a kutatásban való együttmúködésüket kérve. A kutatásban megcélzott valamennyi olyan vállalatot, amely késlekedett a válaszadással telefon útján is megkerestük.

\section{Adattisztítás és a nem-válaszolásból eredó hibák értékelése}

Az elemzés megkezdése előtt értékeltük a nem válaszolásból eredő esetleges hibákat. Armstrong és Overton (1977) útmutatásai alapján jártunk el, akik szerint a lényeges leíró (pl. a vállalat elóállított termékek/szolgáltatások típusa, üzletág, alkalmazottak száma, tulajdonosi szerkezet), illetve a modellbe bevont változók és a válaszadás „gyorsasága” közötti összefüggések, korrelációk utalhatnak arra, hogy bizonyos típusú vállalatok nem, vagy nehezen érhetôk el - és ez szisztematikus hibát eredményez. A vállalatok telefonos megkeresése során kiderült, hogy a válaszadás elutasításának leggyakoribb okai a túl hosszúnak tartott kérdőívvel (összesen 10 sứrún gépelt A4-es oldal) és a válaszadó időhiányával voltak összefüggésben. A statisztikai elemzés (eredményeink nem mutattak ki korrelációt a válaszadási reakcióidő és a kulcs- és leíró változók között) és válaszadás elutasításának okai (amelyek szintén nem leíró-, illetve kulcsváltozó specifikusak) alapján azt gondoljuk, hogy a nem válaszolásból nem okoz mintánkban szisztematikus hibát. Az adatbevitel az SPSS statisztikai programcsomag segítségével történt, amely során elvégeztük az adattisztítást is, vagyis az adatok bármilyen eredetú hibaforrásainak kiszúrését. A visszaellenőrzés során minden tizedik kérdőívet újra egyeztettünk az adatbázisban szereplő adatokkal, amely nem tárt fel szisztematikus hibát.

\section{A minta profilja}

A minta profiljának vizsgálatánál a potenciális (972 vállalatot tartalmazó) és a visszaérkezett (254 vállalat) sajátosságait elemeztük és - ahol lehetôségünk volt - vetettuik össze. Értékeltük munkaköri tapasztalat és beosztás szerint válaszadóinkat. Válaszadóink átlagosan 8 éve dolgoztak a vállalatnál, a legtöbb válaszadó az elsố számú vezetố alatt helyezkedett el a ranglétrán, feltételezhetốn döntési hatáskörrel rendelkezik.
Összevetettük a potenciális és a visszaérkezett minta ágazati megoszlását (11. táblázat).

\section{1. táblázat}

A mintában szereplố vállalatok ágazati besorolás szerinti megoszlása

\begin{tabular}{|c|c|c|}
\hline $\begin{array}{c}\text { Ágazati besorolás } \\
\text { (TEÁOR-kód megfeleltetés) }\end{array}$ & $\begin{array}{c}\text { Potenciális } \\
(\mathrm{N}=972)\end{array}$ & $\begin{array}{c}\text { Visszaérkezett } \\
(\mathrm{N}=\mathbf{2 5 4})\end{array}$ \\
\hline $\begin{array}{l}\text { Mezőgazdaság } \\
\text { (0000-0999) }\end{array}$ & 2,0 & 6,0 \\
\hline $\begin{array}{l}\text { Építőipar } \\
(4100-4550)\end{array}$ & 6,5 & 9,2 \\
\hline \begin{tabular}{|l} 
Szállítás \\
(6000-6323)
\end{tabular} & 4,4 & 5,2 \\
\hline $\begin{array}{l}\text { Nagykereskedelem } \\
(5100-5199)\end{array}$ & 22,0 & 14,4 \\
\hline $\begin{array}{l}\text { Pénzügyi szolgáltatások } \\
\text { (6500-6799, 7100-7199) }\end{array}$ & 4,3 & 6,4 \\
\hline $\begin{array}{l}\text { Bányászat } \\
(1100-1450)\end{array}$ & 0,3 & 0,4 \\
\hline $\begin{array}{l}\text { Feldolgozóipar } \\
(1500-3720)\end{array}$ & 36,5 & 16,4 \\
\hline $\begin{array}{l}\text { Távközlés, hírközlés } \\
\text { (6400-6499, 9200-9299) }\end{array}$ & 2,6 & 4,8 \\
\hline $\begin{array}{l}\text { Kiskereskedelem } \\
(5000-5050,5200-5299)\end{array}$ & 11,1 & 6,8 \\
\hline $\begin{array}{l}\text { Egyéb szolgáltatások } \\
\text { (4000-4099, 6324-6399, } \\
\text { 7000-7099, 7400-7499) }\end{array}$ & 9,6 & 3,2 \\
\hline \begin{tabular}{|l} 
Egyéb \\
(9200-9299)
\end{tabular} & 0,9 & 27,2 \\
\hline Összesen & 100,0 & 100 \\
\hline
\end{tabular}

A potenciális minta ágazati besorolását a $\mathrm{KSH}-$ adatbázis alapján készítettük el. Valamennyi vállalat esetében áttekintettük a fó TEÁOR-kódot ${ }^{12}$, és ezt a kódot feleltettük meg az ágazati besorolásnak. Ez az oka annak, hogy a potenciális mintában alacsony érték ( 0,9 százalék) esik csak az egyéb kategóriába. A TEÁOR-kódok és az ágazati besorolás összekapcsolásának egyik korlátja, hogy a vállalatok esetében a fô TEÁOR-kód nem minden esetben tükrözi a vállalat valódi tevékenységi profilját ${ }^{12}$, ugyanakkor a KSH CD kizárólag a fő TEÁOR-kód „kitöltésére” ad módot.

A visszaérkezett vállalatok ágazati besorolását a válaszadók által megjelölt kategória alapján készítettük el. Itt magas (közel 1/3 az egyéb kategóriák megjelölés), azonban a válaszadói anonimitás miatt nincs lehetőségünk arra, hogy utólag pontosítsuk e vállalatok esetében a besorolást. 
Az ismert kategóriák alapján elmondhatjuk, hogy a mezőgazdaság, a táv- és hírközlés, a pénzügyi szolgáltatások, valamint a szállítás ágazata felülreprezentált mintánkban. A mezôgazdaság kivételével a felülreprezentált (információ-intenzív szolgáltatásként jellemezhetô) ágazatok kedvezóbb válaszadási hajlandósága korábbi kutatásainkban Berács - Keszey et al. (2001) is megfigyelhetô volt. A legalulreprezentáltabb ágazat a feldolgozóipar. Itt azonban érdemes megjegyezni, hogy a feldolgozóipar egy rendkívül tág kategóriát jelöl (pl. élelmiszeripar, könnyưipar, nehézipar stb.). Elképzelhetônek tartjuk, hogy az egyéb kategóriába tartozó vállalatok egy része valójában a feldolgozóiparhoz sorolható.

Miután kutatásunkban - az árbevétel segítségével operacionalizált - nagyvállalatokat vizsgálunk, érthetô, hogy a minta több mint 50 százalékát 300 főnél többet foglalkoztató vállalatok alkotják (12. táblázat).

12. táblázat

A mintában szereplő vállalatok megoszlása az alkalmazottak száma szerint

\begin{tabular}{|c|c|}
\hline Alkalmazottak száma & $\begin{array}{c}\text { Visszaérkezett } \\
(\mathbf{N = 2 5 4 )}\end{array}$ \\
\hline Nem tudja/Nincs válasz & 0,4 \\
\hline Kevesebb, mint 20 & 3,2 \\
\hline $20-99$ & 15,0 \\
\hline $100-299$ & 25,7 \\
\hline $300-499$ & 20,9 \\
\hline $500-999$ & 15,8 \\
\hline $1000-4999$ & 16,6 \\
\hline Több mint 5000 & 2,4 \\
\hline Összesen & $\mathbf{1 0 0}$ \\
\hline
\end{tabular}

A visszaérkezett nagyvállalati mintában magántulajdonban lévő vállalatok szerepeltek a legnagyobb számban; 10 százalék volt az állami tulajdonban lévő vállalatok aránya (13. táblázat).

13. táblázat

A mintában szereplő vállalatok megoszlása a tulajdonosi szerkezet szerint

\begin{tabular}{|c|c|}
\hline Tulajdonosi forma & $\begin{array}{c}\text { Visszaérkezett } \\
(\mathbf{N = 2 5 4 )}\end{array}$ \\
\hline $\begin{array}{c}\text { Állami tulajdonban van } \\
\text { vállalat }\end{array}$ & 10,0 \\
\hline $\begin{array}{c}\text { Többségi magyar magántulajdonban lévő́gi külföldi magántulajdonban lévő } \\
\text { vállalat }\end{array}$ & 36,7 \\
\hline $\begin{array}{c}\text { Összesen } \\
\text { Oon }\end{array}$ & $\mathbf{1 0 0}$ \\
\hline
\end{tabular}

\section{Az elemzések módszertana}

A tanulmány elkészítése során az SPSS 10.0 statisztikai szoftverrel dolgoztunk. A modellt lineáris regresszióelemzés segítségével készítettük el. A modellben szereplő konstrukciókat megbízhatóság szempontjából a nemzetközi marketingkutatásokban alkalmazott Gerbing és Anderson (1988) által leírt módszer alapján teszteltük (egydimenziójúság vizsgálata, Cronbachalpha mérôszám kalkulálása, megerősítő faktorelemzés, diszkriminanciaérvényesség vizsgálata). A regressziós egyenletek felállítása előtt Mason és Perreault (1991) útmutatásai alapján kizártuk a multikollinearitás kockázatát.

\section{Összegzés}

A marketing hagyományosan nem tartozik a kiemelt informatikai támogatást élvező területek közé. A keresleti oldal vizsgálata alapján megállapíthatjuk, hogy a magyar marketingvezetók pozitív informatikával kapcsolatos attitúdje ellenére 88 százalékuk úgy véli, hogy az informatikánál lényegesebbek a szórványinformációk és a piackutatás a piaci tájékozódás során.

Nagyvállalataink fớként kereskedelmi marketingadatokat (pl. saját termékek árai, kereskedelmi partnerek alapadatai) rögzítenek IT-alkalmazások segítségével, míg a versenytársakkal vagy épp a vállalat piaci teljesítményével kapcsolatos információk csak elvétve érhetôk el számítógépes alkalmazásokon keresztül - jóllehet ezek kulcsfontosságúak a klasszikus marketingfeladatok elvégzéséhez.

A CRM-rendszerek egy évtizeddel ezelőtt történô megjelenése forradalmasítani tưnt a marketing és informatika kapcsolatát, ez a szegmens vált a vállalati informatikai piac katalizátorává, a jelenleg is nyolcmilliárd dolláros piac töretlen, átlagosan 9 százalékos fejlődésére számítanak továbbra is az elemzók. A CRM-rendszereket egyfajta „csodavárás” lengi körül, a vezetôk egy része ebben látja a hatékonyság növelésének zálogát, míg mások egyenesen a marketing új „mantrájának” tekintik. A téma iránti populáris figyelem ellenére kevesebb rendszerezett akadémiai igényú ismeret áll rendelkezésre. Az utóbbi években a nemzetközi és magyar marketingakadémiai szaksajtóban is számos hiánypótló publikáció jelent meg.

Kutatásunk eredményei szerint a magyar valóság nem tükrözi a napi sajtóból kiolvasható eufóriát, nagyvállalataink mindössze 13 százaléka rendelkezett 2003-ban olyan CRM-rendszerrel, amelyek ismert nagy nemzetközi rendszerházakhoz köthetôk. Méréseink szerint a magyar piacon az SAP CRM-rendszere a piacvezető. A legtöbb CRM-rendszert alkalmazó ma- 
gyar nagyvállalat saját fejlesztésú szoftverrel dolgozik. A legnagyobb árbevétellel rendelkező magyar vállalatok harmada alkalmaz valamilyen informatikával támogatott CRM jellegú megoldást, második harmada tervezi, míg harmadik harmada nem is alkalmaz, és nem is tervez CRM rendszert kialakítani.

Vizsgáltuk, hogy milyen tényezók határozzák meg az informatika marketingmenedzsmentben betöltött szerepét. Eredményeink szerint az IT-rendszerek főleg a jól strukturált problémák megoldásánál jelentenek segítséget. A nagyvállalatok által alkalmazott marketingmenedzsment-tevékenységet támogató informatikai alkalmazások észlelt hasznosságát leginkább az határozza meg, hogy mennyire felhasználóbarát a rendszer, mennyire tudja a vállalati szakember más kollégák segítsége nélkül önállóan is használni a szoftvert. Az informatikai rendszerekben rögzített, a marketingmunka szempontjából releváns adatok köre és mélysége szintén hatással van arra, mennyire használják a vezetốk a számítógépeket. Kutatásunk tanulságai szerint nem elegendő adatokkal ,feltölteni” az IT-rendszert, de a motivációs rendszert is úgy kell kialakítani, hogy fontosnak tartsák a számítógépekben tárolt információk felhasználását a vezetők, csak így lehet az informatika a marketingmenedzsment támogatásának hatékony eszköze. Az informatikai rendszerek hasznosságának vezetői megítélésére hatással vannak a vállalaton belüli információmegosztási minták is. Eredményeink szerint az informális vállalaton belüli kommunikáció segíti a marketingvezetőket abban, hogy az IT-rendszerekben rögzített „,száraz”, kvantitatív adatokat értelmezzék, és munkájuk során felhasználják. Eredményeink szerint a vállalati formalizáltság és - külföldi vállalatok esetében - a kapcsolat szorossága az anyavállalattal is hozzájárul ahhoz, hogy a marketingmenedzserek mennyire tartják fontosnak az informatikai alkalmazásokat.

\section{Lábjegyzetek}

1 A tanulmány a T037857 számú, „Marketingmenedzsment tevékenységet támogató információrendszerek és a piaci tudás felhasználása Magyarországon" c. OTKA-kutatás, valamint a Bolyai János kutatási ösztöndíj támogatásával készült.

2 A CRM-rendszerekben általában a következő adatokat rögzítik a cég vevőitől: a vevoók vásárlásai beleértve a vásárlás árát, dátumát, a vásárolt szolgáltatást; vevôi preferenciák, leíró adatok - demográfiai és pszichográfiai adatok; illetve a marketingakciókra való reagálás.

3 Az angol „market intelligence” kifejezésnek egyelőre nincs széles körben elfogadott és konszenzuson alapuló magyar megfelelője. A kifejezés a piaci szórványinformációk gyưjtését, rendszerezését és összekapcsolását jelenti. Bauer és Berács (2006) marketing-felderítésnek fordítja, míg Kotler (1991) magyar nyelvú kiadásában a marketingmegfigyelés (6. oldal) kifejezéssel találkozhatunk. Az üzleti gyakorlatban a szó tükörfordítása (intelligencia) túnik létjogosultságot nyerni (pl. üzleti intelligencia-megoldások). A tanulmányban szinonimaként használjuk az intelligencia, megfigyelések és értesülések kifejezéseket.

${ }^{4}$ ANOVA egy szempontos szóráselemzés, illetve kereszttáblák elemzése segítségével végeztük ezt a vizsgálatot.

5 A magyar vállalatoknál e területek informatikai támogatottsága a legmagasabb szintú. A „Versenyben a világgal” c. kutatássorozatban mind 1996-ban, mind 1999-ben a számviteli és a pénzügyi informatikai rendszerek integráltságának mértéke volt a legmagasabb (Drótos = Szabó, 2001).

${ }^{6}$ A táblázat azon nagyvállalatok százalékos arányát tartalmazza, amelyek információrendszerében - ha nyomokban is - de tárolják a vizsgált piaci adatokat. Ennek megfelelően a százalékos arányt a következóképp számítottuk: 1-(n egyáltalán nem tartalmazza a rendszer / $\mathrm{N}$ érvényes).

${ }^{7}$ A belga kutatásban 400 vállalat - nem csak nagyvállalatok megkérdezésével születtek az eredmények; a forrás azonban nem közöl információkat arra vonatkozóan, hogy ez a minta reprezentálja-e valamilyen ismérv szerint a belgiumi vállalatokat. Ezzel szemben mi felmérésünkben kifejezetten a nagyvállalatokra koncentráltunk.

${ }^{8}$ Felmérésünkben - a Magyarországon múködő integrált vállalatirányítási rendszerházakat és informatikai tanácsadó cégeket teljes körúen megkérdezve - vizsgáltuk, hogy az ezredforduló után a magyarországi vállalatok milyen kereskedelmi forgalomban kapható vállalatirányítási (Enterprise Resource Planning / ERP) rendszerek közül választhatnak, illetve ezek az alkalmazások mennyiben támogatják a marketingmunkát. A mintavételi keret összeállítása során támaszkodtunk az Informatikai Vállalkozások Szövetségének honlapján található céginformációkra, a Szaknévsorban tárolt információkra és a Dunn \& Bradstreet adatbázisára. Az összegyújtött 1 szoftverforgalmazással, illetve rendszerimplementációval foglalkozó vállalat mindegyikét megkerestük levél útján; így tájékozódva az általuk forgalmazott IT-termékek funkcióiról. Kutatásunkban 24 százalékos válaszadási arányt értünk el.

9 2000-ben 572 a magyar vállalat megkérdezése alapján.

${ }^{10}$ A marketingorientáció olyan vállalati gazdálkodási forma, amely során érvényesül a marketingfunkció dominanciája más vállalati funkciók felett. Az ilyen vállalat a marketingkoncepcióra építve, a piackutatást a vevôkön túl a versenytársak irányába is kibóvíti. (Bauer = Berács 1998)

${ }^{11}$ A nagyvállalatokat éves négymilliárd forintot meghaladó árbevétellel operacionalizáltuk.

${ }^{12}$ Az UNILEVER TEÁOR kódja például a margaringyártás. A TEÁOR kód alapján a vállalat a feldolgozó iparba kerülne besorolásra. Ugyanakkor a vállalat tevékenységi profilja alapján a nagykereskedelmbe kellene, hogy kerüljön.

\section{Felhasznált irodalom}

Adams, B. - Berner, E.S. et al. (2004): Applying Strategies to Overcome User Resistance in a Group of Clinical Managers to a Business Software Application: A Case Study. Journal of Organizational and End User Computing, 16(4), p. 55-64.

Alavi, M. - Joachimsthaler, E.A. (1992): Revisiting DSS Implementation Research: A Meta-Analysis of the 
Literature and Suggestions for Researchers. MIS Quarterly, 16 (March), p. 95-113.

Anderson, W.E. - Mittal, V. (2000): Strengthening the satisfactionprofit chain. Journal of Service Research, 3 (2) p. 107-121.

Armstrong, J.S. - Overton, T.S. (1977): Estimating Nonresponse Bias in Mail Surveys. Journal of Marketing Research, 14(August), p. 396-402.

Bauer, A. - Berács, J. (1998): Marketing. Aula Kiadó, Budapest

Bauer, A. - Berács, J. (2006). Marketing. Aula Kiadó, Budapest

Berács, J. (2003): A piaci teljesítménymutatók alkalmazásáról. Üzleti teljesítmény és Marketing - Új irányzatok a marketingstratégiában 4. - Szerk.: Berács, J. Budapesti Közgazdaságtudományi és Államigazgatási Egyetem, Marketing Tanszék, Budapest

Berács, J. - Keszey, T. - Sajtos, L. (2001): A magyarországi vállalatok marketing megközelítése, stratégiája és teljesítménye - OTKA kutatási jelentés T030028. Budapest, Budapesti Közgazdaságtudományi és Államigazgatási Egyetem Marketing Tanszék, p. 1-178.

Blattberg, R.C. - Getz G.C. - Thomas, J.S. (2001): Managing Customer Acquistion. Direct Marketing, 64(6), p. 41-54.

Bokker, S. (2002): Informatikai rendszerek a sikeres vállalkozásokért. Marketing és Menedzsment, 2(36), p. 70-73.

Büdy, L. (2001): A CRM lehetôségei a vállalati gyakorlatban. Marketing és Menedzsment, (1), p. 25-29.

Curchill, G.A. (1979): A Paradigm for Developing Better Measures of Marketing Constructs. Journal of Marketing Research, 16 (February), p. 64-73.

Davis, F.D. (1989): Perceived Usefulness. Perceived Ease of Use and User Acceptance of Information Technology. Management Information Systems Quarterly, vol.13. (September), p. 319-340.

Day, G.S. (2003):. Creating a Superior Customer-Relating Capability. Sloan Management Review, 44 (3), p. 77-82.

Deshpandé, R. - Zaltman, G. (1982): Factors Affecting the Use of Market Research Information: A Path Analysis. Journal of Marketing Research, 19 (February), p. 14-31.

Drótos, G. - Szabó, Z. (2001): Vállalati informatika Magyarországon az ezredfordulón - Mítosz és valóság. Vezetéstudomány, 32 (2), p. 17-24.

Dunn - Humby (1990): Use and Attitudes to Computers in Marketing, Dunn Humby Associates

Economist (2001): Survey of Software - The Age of Cloud, The Economist

Fletcher, K. (1995): Marketing Management and Information Technology, Prentice Hall, London

Gerbing, D. - Anderson, J. (1988): An Updated Paradigm for Scale Development Incorporating Unidimensionality and its Assesment. Journal of Marketing Research, 25(May), p. 186-192.

Glazer, R. (1999): Winning in Smart Markets. Sloan Management Review, 40(4), p. 59-69.

Gross, A. - Hartley, R. et al. (1999): Business Education and Management Training in the Old and New East Europe.
Managing Business in Hungary. Szerk.: J. Berács and A. Chikán. Akadémiai Kiadó, Budapest

Hart, W.C. (2007): Beating the Market with Customer Satisfaction. Harvard Business Review, 72 (3), p. 30.

John, G. - Martin, J. (1984): Effects of Organizational Structure of Marketing Planning on Credibility and Utilization of Plan Output. Journal of Marketing Research, 21(May), p. 170-183.

Kamakura, W.A. - de Rosa, F.V.M. - Mazzon, J.A. (2003): Cross-Selling Through Database Marketing: A Mixed Data Factor Analyzer for Data Augmentation and Prediction. International Journal of Research in Marketing, 20 (1), p. 45-65.

Keszey, T. (2003): Marketing menedzsment tevékenységet támogató informatikai rendszerek elméleti áttekintése és magyarországi helyzetképe. Budapesti Közgazdaságtudományi és Államigazgatási Egyetem, Kézirat, Budapest

Keszey, T. (2004): A piackutatásból származó információk vezetôi felhasználása és az arra ható tényezók vizsgálata. Marketing Tanszék. Budapest, Budapesti Közgazdaságtudományi és Államigazgatási Egyetem, Gazdálkodástudományi szakosítású Ph.D. program, Kézirat, 171 old.

Kotler, P. (1991): Marketing management - elemzés, tervezés, végrehajtás és ellenôrzés. 4. változatlan kiadás, Múszaki Könyvkiadó, Budapest

Kotler, P. - Keller, K.L. (2006): Marketingmenedzsment, Akadémiai Kiadó, Budapest

Langerak, F. - Commandeur, H. et al. (1998): ICTMogelijkheden vaak onbenut, Onderzoek naar gebruik van ICT dood marketingafdelingen in Belgie. Tijdschrift voor Marketing 32 (November), p. 18-21.

Leonard-Barton, D. - Deschamps, I. (1988): Managerial Influence in the Implementation of New Technology. Management Science, 34 (10) p. 1252-65.

Leverick, F. - Litter, D. et al. (1997): The Role of IT in the Reshaping of Marketing. Journal of Marketing Practice: Applied Marketing Science, vol.3(no.2), p. 87-106.

Low, G.S. - Mohr, J.J. (2001): Factors Affecting the Use of Information in the Evaluation of Marketing Communications Productivity. Journal of the Academy of Marketing Science, 29 (Winter), p. 70-88.

Maltz, E. - Kohli, A.K. (1996): Market Intelligence Dissemination Across Functional Boundaries. Journal of Market Research, 33 (February), p. 47-61.

Mason, C.H. - Perreault, W.D.J. (1991): Collinearity, Power and Interpretation of Multiple Regression Analysis. Journal of Marketing Research, 28 (August), p. 268-280.

Mester, Cs. (2006): Hogyan válik a CRM a vállalatok versenyképességének meghatározó elemévé? Vezetéstudomány, 37 (különszám), p. 87-97.

Moorman, C. - Zaltman, G. - Deshpandé, R. (1992): Relationships Between Providers and Users of Market Research: The Dynamics of Trust Within and Between Organizations. Journal of Marketing Research, 24 (August), p. 314-328. 
Polányi, M. (1994): Személyes tudás - Úton egy posztkritikai filozófiához. Atlantisz Könyviadó. Budapest

Rigby, D.K. - Reichheld,F.K. - Schefter, P. (2002): Avoid the Four Perils of CRM. Harvard Business Review, 80(2), p. 101-111.

Swift, R.S. (2001): Accelerating Customer Relationships: Using CRM and Relationship Technologies. Prentice Hall, Upper Saddle River, NJ

Szabó, K. - Hámori, B. (2006): Információgazdaság. Digitális kapitalizmus, vagy új gazdasági rendszer? Akadémiai Kiadó, Budapest

Taylor, R.N. (1975): Age and Experience as Determinants of Managerial Information Processing and Decision Making Performance. Academy of Management Journal 18 (March), p. 74-81.

van Bruggen, G.H. - Wierenga, B. (2005): When are CRM Systems Successful? The Perspective of the User and of the Organization. Rotterdam, Erasmus Research Institute of Management (ERIM), p. 1-50.

Venkatesh, V. (2000): Determinants of perceived ease of use: Integrating control, intrinsic motivation, and emotion into technology acceptance model. Information Systems Research 11(4), p. 342-65.
Wierenga, B. - v. Bruggen, G. H. (2000): Marketing Management Support Systems: Principles, Tools and Implementation. Kluwer Academic Publishers, Boston

Wierenga, B. - Ophuis, O.P.A.M. (1997): Marketing Decision Support System Adoption, Use and Satisfaction. International Journal of Research in Marketing 14 (July), p. 275-290.

Winer, R. S. (2001): A Framework for Customer Relationship Management. California Management Review, 43(4), p. 89-105.

Zaltman, G. - Duncan, R. et al. (1973): Innovations and Organizations. John Wiley\&Sons, Inc., New York

Zinkhan, G.M. - Joachimsthaler, E.A.et al. (1987): Individual Differences and Marketing Decision Support Systems Usage and Satisfaction. Journal of Marketing Research vol.24 (May), p. 208-214.

Zoltayné Paprika, Z. (2002): The Competitiveness of Hungarian Managers. National Competitiveness in Global Economy - The Case of Hungary. Szerk.: A. Chikán, E. Czakó and Z. Zoltay-Paprika. Akadémiai Kiadó. Budapest

A cikk beérkezett: 2007. 3. hó.

Lektori vélemény alapján átdolgozva: 2007. 4. hó

\section{E SZÁMUNK SZERZÖI}

Dr. Hámori Balázs, egyetemi tanár, kutatásvezető, Budapesti Corvinus Egyetem; Dr. Szabó Katalin, egyetemi tanár, Budapesti Corvinus Egyetem; Hurta Hilda, Ph.D. hallgató, Szent István Egyetem; Tóth László, Ph.D. hallgató, Szegedi Egyetem ; Dr. Pfohl, Hans-Christian, egyetemi tanár, Darmstadti Múszaki Egyetem; Dr. Gaál Zoltán, egyetemi tanár, Pannon Egyetem; Dr. Szabó Lajos, egyetemi docens, Pannon Egyetem; Gomm, Moritz, egyetemi tanársegéd, Darmstadti Múszaki Egyetem; Bode, Alexander, egyetemi tanársegéd, Darmstadti Múszaki Egyetem; Dr. Keszey Tamara, egyetemi docens, Budapesti Corvinus Egyetem; Dr. Székely Ákos, szemináriumvezető, Budapesti Corvinus Egyetem; Dr. Zoltay Paprika Zita, egyetemi docens, Budapesti Corvinus Egyetem 